UNIVERSIDADE DE SÃO PAULO

ESCOLA DE COMUNICAÇÕES E ARTES

LUCAS JARA SOARES

\title{
A arte em suspenso
}

Crítica, processo e a dimensão transcendente

São Paulo

2014 
LUCAS JARA SOARES

\section{A arte em suspenso}

Crítica, processo e a dimensão transcendente

Dissertação (corrigida) apresentada à Escola de Comunicações e Artes da Universidade de São Paulo para obtenção do título de mestre em Artes Visuais. Área de Concentração: Poéticas Visuais.

Orientador: Prof. Dr. Geraldo Souza Dias

A versão original pode ser encontrada na Bibliioteca da Escola de Comunicações e Artes e na Biblioteca Digital de Teses e dissertações da USP (BDTD).

São Paulo 
Autorizo a reprodução e divulgação total ou parcial deste trabalho, por qualquer meio convencional ou eletrônico, para fins de estudo e pesquisa, desde que citada a fonte.

Catalogação na Publicação

Serviço de Biblioteca e Documentação

Escola de Comunicações e Artes da Universidade de São Paulo

Dados fornecidos pelo(a) autor(a)

Soares, Lucas Jara

A arte em suspenso: crítica, processo e a dimensão

transcendente / Lucas Jara Soares. -- são Paulo: L. J.

Soares, 2014.

74 p.: il.

Dissertação (Mestrado) - Programa de Pós-Graduação em Artes Visuais - Escola de Comunicações e Artes / Universidade de são Paulo.

Orientador: Geraldo Souza Dias

Bibliografia

1. processo crítico 2. arte, vida e filosofia 3. estética e política 4. escritos de artista I. Dias, Geraldo Souza II. Título. 

Lucas Jara Soares

A arte em suspenso: crítica, processo e a dimensão transcendente.

Dissertação apresentada à Escola de Comunicação e artes da Universidade de São Paulo para obtenção do título de Mestre em Artes Visuais

Aprovado em:

Banca Examinadora

Prof. Dr. Instituição:

Julgamento: Assinatura:

Prof. Dr. Instituição:

Julgamento: Assinatura:

Prof. Dr. Instituição:

Julgamento: Assinatura: 
Aos que são artistas sem saber. 


\section{Agradecimentos}

à CAPES, pelo apoio financeiro sem o qual a presente pesquisa não poderia ter sido realizada;

a meu orientador, Geraldo Souza Dias, por ter me confiado autonomia suficiente para que eu conduzisse meu mestrado no sentido que me pareceu mais urgente;

às minhas bancas de qualificação e defesa, constituídas por Tadeu Chiarelli, Cristina Freire, e Dora Longo Bahia;

aos professores e funcionários da Universidade de São Paulo, e à Zimbabwe, minha república, que proporcionaram a necessária estrutura física onde a maior parte desta pesquisa foi realizada;

aos autores que li; em particular, a Márcio Suzuki,

aos que de alguma forma me acompanharam neste período em São Paulo: Gutto Chaves; Julian Osuna Mello; Francisco Machado Meyer; Evandro Rozentalski; Leandro Paixão; Radamés Rocha; Carlos Monroy; Ivan Alejandro; Tiago Gomes; Sérgio Juanca; Fabrícia Jordão; Antonio Antunes; Luise Prates; Taciane Domingues; Danilo Acqua; Cássila Soares; Josefy Ramaldes; Janaína Mendes dos Reis; Gilberto Franc; Alex Bira; Gustavo Oliveira; Maricota; Jasmin Lindner; Luciene Fernanda; Luis Fernandes (Índio); Braian; Flávia Zimbres; Pamela Pa Pe; Luis García;

àqueles que mais de longe estiveram de algum modo presente: Amundaim; Anne Marie Sampaio; Angelo Luz; Bruno Oliveira; luri Kato; Diogo Messias; Giorgia Conceição; Henrique Saidel; Geraldo Leão; Rafael Budni; Carlos Kenji; Paulo Reis; Carlos Eduardo Brandl; Isabela Baena; Hugo Goss; Débora Marques; Bárbara Renata; Bruna Riello; Daniel Venturi; Paula Maia, Alessandra Nezzi; Rodolfo Silva; Felipe Minella; Patrícia Minella; Vânia Wollmann; Patrícia Fujita; Irena Menk; Gisele Morais; Leca Monteiro; Ari Niehues, Ione Vero;

à minha família;

em particular à meu irmão, de quem tenho saudades;

e sobretudo à meus pais, por serem quem são; amo vocês.

Obrigado! 


\section{Resumo}

A presente pesquisa recupera o projeto de aproximação entre arte e vida, e considera, a partir da própria produção escrita no interior da academia, a distância entre arte e não-arte. Pensa-se que ao tornar aspectos da arte consciente, o artista contemporâneo que escreve aproxima-se da filosofia, e assim, confirma "profecias" do pensamento romântico anunciadas já no século XVIII. Em relação à tradição mais ampla a que se vincula esta filosofia, podemos verificar algumas das consequências mais radicais do projeto vanguardista de aproximação entre arte e vida. Pois durante aquele período, a arte foi reconhecida por uma série de pensadores como a prática humana de mais elevada significação. Compreendendo então a nós mesmos, contemporaneamente, muito à margem do campo tradicional da arte - e tomando liberdades de artista em relação à história -, reconsideramos noções centrais a esta tradição, como as de espiritualidade e genialidade, pensando-as em relação a proposições como a de que, após Duchamp, todos somos artistas, e qualquer coisa pode ser arte. Surpreendentemente, estas ideias já estavam de certo modo presentes no pensamento romântico quando então se considerou que todos somos gênios, e que teríamos apenas que atentar para as condições propícias a seu desenvolvimento. Reconhecendo então afinidades entre a filosofia e a arte no que se refere a um amplo projeto comum de operar sobre as limitações da experiência humana, e ao desejo de fazer ascender a potência do indivíduo, propõe-se a admissão da filosofia - não como coisa teórica ou abstrata, mas como modo de vida! - no lugar da arte. Compreende-se, claramente, que a filosofia não é unívoca, mas acredita-se na importância da consideração poética da profunda potência de transformação de toda aquela [filosofia] que admite a possibilidade de sua realização na vida, como arte. 


\begin{abstract}
This research retrieves the project of approaching art and life, and considers, from the written production itself within the academy, the distance between art and non-art. We understand that by making aspects of art conscious, the contemporary artist who writes gets closer to philosophy, and thus confirms "prophecies" of the romantic thought already announced in the eighteenth century. Regarding the broader tradition that this philosophy is linked to, we can consider some of the most radical consequences of the avant-garde project of rapprochement between art and life. For during that period, art has been recognized by a number of thinkers as the human practice of highest significance. Then understanding ourselves, contemporaneously, greatly on the margins of the traditional field of art - and taking artist liberties in relation to history - we have reconsidered notions which are central to this tradition, such as spirituality and genius, considering them in relation to propositions such as that, after Duchamp, we are all artists, and anything can be art. Surprisingly, these ideas were already in a certain way present in the romantic thought when it was considered that we are all geniuses, and we would just have to pay attention to the conditions conducive to our development. Then recognizing affinities between philosophy and art in relation to a large joint project to operate on the limitations of human experience, and the desire to ascend the power of the individual, the admission of philosophy is proposed - not as something theoretical or abstract, but as a way of life! - taking the place of art. It is clearly understood that philosophy is not univocal, but, rather, what we believe to be important to consider is the poetic account of the deep transformation power of all philosophy which admits the possibility of its fulfillment in life, as art.
\end{abstract}


-Sobre a Centralidade da Estética 1 (o artista fora de seu lugar).................................................... 8

-SaCdE.2 (sobre o paradoxo de um trabalho escrito no interior de um programa de Poéticas Visuais) ............ 11

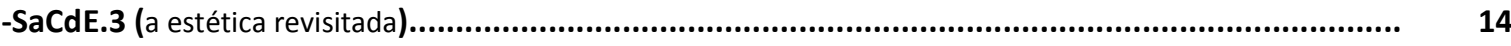

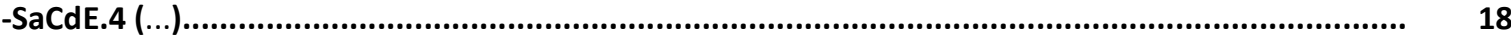

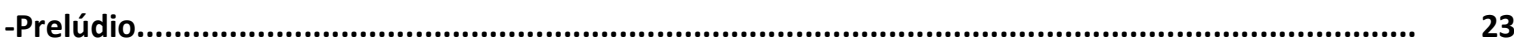

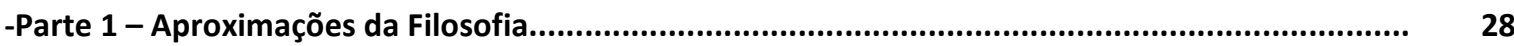

-1.0 Questão de consciência e inconsciência........................................................................ 32

-1.1 Notações filosóficas sobre a ideia de genialidade................................................................... 33

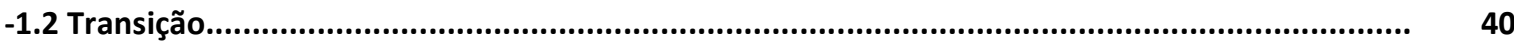

-Parte 2 - Em direção à vida como arte - A filosofia realizada - o exemplo da pintura.................... 47

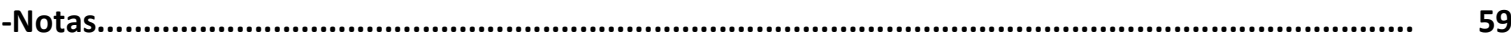

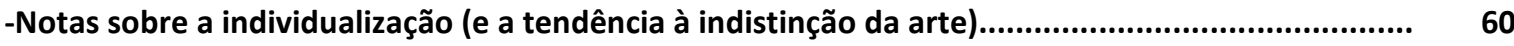

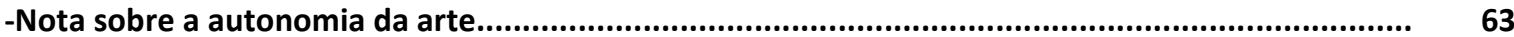

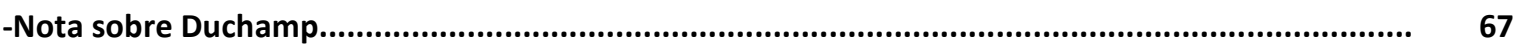

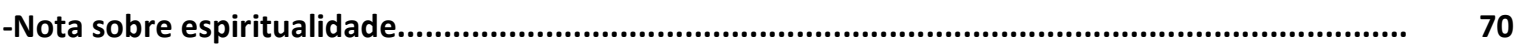

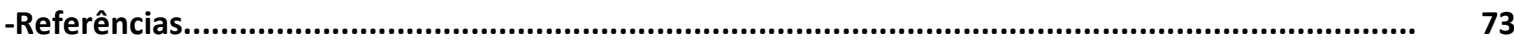


"os trabalhos de teoria da arte são parte do kit do artista conceitual, e, como tal, quando tomados pelo artista conceitual, podem ser considerados um trabalho de arte conceitual?"

Art \& Language,

(Citado em Além da Pureza Visual, de Ricardo Basbaum) 
"Escrever nada tem a ver com significar, mas com agrimensar, cartografar, mesmo que sejam regiões ainda por vir."

Deleuze e Guattari

Os pequenos capítulos a seguir possuem algo de introdução e de conclusão. Trata-se de um apanhado geral, realizado após minha defesa, quando então foi sugerido por minha banca que fizesse as alterações e os acréscimos que julgasse pertinentes a partir do que foi dito. De certo modo, o que se apresenta aqui adianta e atropela uma série de questões tratadas em minha pesquisa, mas se isso ocorre, creio que a clareza será um bom preço.

\section{Sobre a Centralidade da Estética - 1}

(o artista fora de seu lugar)

Penso no artista como uma espécie de filósofo que sente precisar de outros sentidos - mais de que dispõe a filosofia comum! -, para dizer aquilo que quer dizer ${ }^{1}$. Como se o que interessasse ao artista considerar fosse tão urgente que exigisse presentificação imediata; daí que trabalhe com obstinação na própria forma de seu enunciado. Ao ocupar-se com a significação sensorial da forma, como o escultor que lapida a pedra, o artista é o único que verdadeiramente compreende a dimensão estética da Ideia que, no princípio de seus trabalhos, move tanto ele quanto o filósofo. 0 gesto do pintor, como uma sutil variação de tons, para o músico, ou um pequeno movimento do quadril, para o dançarino, define com precisão aquele conhecido elemento "incomunicável”, e fundamental, da arte. O "discurso" do trabalho do artista, se quisermos considerar assim, não se refere aos sentidos que são de seu interesse, como se estes estivessem do lado de fora, mas antes, o corpo de seu discurso deixa-se impregnar por seus sentidos de tal forma que ele passa de algum modo a encarná-los, ainda que a despeito de sua própria intenção; para o artista, a forma é o discurso.

Quando afastado de seu meio habitual de trabalho, como quando um pintor assume a posição de falar sobre seu trabalho, é comum que o artista, vendo-se então limitado ao uso de coisas, como palavras, com as quais nem sempre tem muita familiaridade, revele certo sentimento de insuficiência ou inadequação para o tratamento do que de fato lhe interessa; como se algo lhe escapasse, sem fazer justiça à potência daquilo que, por ele - ou, mais propriamente, por algo como

${ }^{1}$ Com "filosofia comum", me refiro àquela que, distante da vida, compreende a si mesma num campo puramente ideal e abstrato. 
uma "necessidade interna", como dizia o pintor Iberê Camargo -, quer significar. Se o caso for o de usar palavras, seria preciso que o artista não as tomasse simplesmente para falar sobre seu trabalho, mas que as tomasse como trabalho. Isto exigiria que a palavra não fosse usada apenas, como instrumento ou meio, mas que nela fosse reconhecido um fim; o que bastaria para que as palavras não mais limitassem, mas libertassem, e para que então o artista se visse muito mais próximo do poeta, do que do filósofo em seu sentido mais comum. Como nem todo artista é exatamente um poeta, nem propriamente um filósofo, aquela "necessidade interna" de fazer ver ou sentir algo que não se deixa comunicar propriamente por conceitos muitas vezes ocasiona uma fala, talvez um tanto paradoxal, em que a falta, como o excesso, também são significativos.

Se preservamos estas mesmas ideias em "campo ampliado", e se nos esforçamos para considerar, junto a Thierry de Duve, que hoje somos todos artistas ${ }^{2}$, então precisaríamos admitir esta singularidade para muito além dos meios específicos em que tradicionalmente atuam os autoproclamados, e assim reconhecidos, artistas. Certo que apenas de modo muito particular podese considerar a dimensão poética de nossas falas e produções mais cotidianas, assim como uma eventual proximidade destes fazeres com qualquer tipo de "filosofia encarnada"; mas quem de nós não revela sentidos, ainda que inconscientes, com as formas que propõe ao mundo? Se mesmo o filósofo mais pretensamente abstrato e idealista, na medida em que escreve ou fala, propõe formas, e com elas, sentidos que podem escapar às intenções de seus autores... De qualquer modo, a arte, se a identificamos nestes casos menos convencionais, não encontra aquele aspecto bem desenvolvido, polido e acabado com o qual estamos tradicionalmente habituados. Se, não obstante, para tentar compreender o que nos propõe Thierry de Duve, decidirmos experimentar considerar as coisas em geral como arte, alterando nossa percepção usual em relação a elas, tomando-as com o apropriado cuidado de trazer suas dimensões estéticas à consciência, antes de qualquer julgamento, descobriríamos certamente um mundo novo. É a meu ver o que se pretende com a inclusão de algo inusitado para os padrões tradicionais da arte, como a pichação, em uma das últimas grandes bienais de São Paulo. Como este caso bem exemplifica, o que se contempla a partir desta premissa mais generalizante da arte nem sempre é tão facilmente apreciável. O que se pede, porém, é justamente a apreciação de coisas não geralmente apreciadas, pela própria diversidade de questões que elas trazem à tona; não para que sejam simplesmente admiradas, mas para que se faça crítica. Trata-se então de uma manobra estratégica que permite assumir em definitivo a dimensão política da

\footnotetext{
${ }^{2}$ Segundo de Duve, se aceitamos os ready-mades de Duchamp como arte, então esta seria uma decorrência necessária: “...seu tipo particular de arte, o ready-made, não surgiu nem da crença, nem da esperança de que todos podem ou deveriam ser artistas. Em vez disso, reconheceu - e bem razoavelmente - o 'fato' de que todos já tinham se tornado artistas. Diante de um ready-made, não existe mais qualquer diferença técnica entre fazer e apreciar arte". Thierry de Duve. "Kant depois de Duchamp". Revista do Mestrado em História da Arte EBA - UFRJ, 1998.
} 
estética. Pois se todos produzimos arte ao longo de nossas vidas, independente do reconhecimento do estatuto destas produções, por que experiências significativas nos parecem tão raras e por que, por conseguinte, a grande maioria de nossas experiências nos parecem tão pouco significativas?

Alguém poderia inferir, de um ponto de vista possivelmente mais moderno, que boa parte dos artistas reconhecidos depende de conhecimentos e meios, técnicos e específicos, para a produção de suas obras; o que tornaria difícil admitir que artistas que nem sequer sabem que são artistas, e que assim, nem bem possuem algo como um "meio específico", possam propiciar com seus trabalhos experiências verdadeiramente significativas. De fato, não é por proclamar que todos somos artistas que todos que se metam com telas e tintas pintarão "obras-primas". Não se trata disso. Certas obras dependem de espaços, materiais, técnicas, e certo nível de especialização do artista, não há dúvida. O projeto de fusão entre arte e vida, ${ }^{3}$ no entanto, seria impensável se este fosse o caso para a arte de modo geral. Se tal nível de especialização fosse mesmo necessário - e se, afinal, é impossível apreender todos os conhecimentos e meios técnicos de que dispõe "a vida" para que todas as coisas possam ser operadas com maestria correlata a do pintor com suas cores -, o artista cessaria de fazer arte tão logo se afastasse de seu meio específico de trabalho, seu ateliê e suas ferramentas, no caso do pintor, sem nem bem se colocar a questão de tomar da mesma forma as coisas que tomam seu tempo para além destes espaços; ou, se mesmo assim lhe fosse dada a ideia de transformar sua vida em arte, provavelmente se enfurnaria em seu ateliê, e não faria outra coisa que pintar. Obviamente, o projeto de aproximação entre arte e vida possui sentido muito diverso, e se não é seu intuito justamente a transformação destes outros meios, para além dos meios específicos de arte, por onde transitam os "não-artistas", é certamente ao menos a transformação do nosso modo habitual de encará-los.

O interesse em proclamar que todos somos artistas, assim como o interesse pela não arte e por materiais não propriamente artísticos, tem a ver com uma mudança de enfoque em relação ao caráter especializado do trabalho do artista. Sabe-se bem que na contemporaneidade raramente os artistas se restringem a uma determinada técnica, como se muito mais do que uma habilidade muito específica, importasse desenvolver uma qualidade anterior, não apenas relacionada a um domínio histórico e conceitual, mas principalmente a um modo de proceder no mundo. É de certo modo a não especialização o que o artista espanhol Valcárcel Medina, por exemplo, defende quando afirma "não mais a arte parcial e fragmentária, a arte para ser contemplada, a arte oásis, mas sim a arte

\footnotetext{
${ }^{3}$ Para evitar mal-entendidos, compreende-se, como será dito mais adiante, que a arte já ocorra, como sempre ocorreu, natural e necessariamente, junto à vida. O "projeto de fusão entre arte e vida", entretanto, se refere ao projeto de resistência ao distanciamento ocasionado pela delimitação da arte a espaços e meios específicos durante o início do período moderno. Aqui, portanto, será referido assim o projeto vanguardista orientado para uma coincidência definitiva entre arte e vida, de modo que a vida não possa ser admitida distante do estado de arte.
} 
para ser vivida, a arte habitada, a arte tudo" ${ }^{4}$. Trata-se, a meu ver, de um interesse no que resulta daquela mudança de percepção necessária para que todas as coisas sejam tomadas como arte, como se aquela atenção desinteressada do pintor num momento de criação de uma de suas telas se estendesse a todas as coisas, de modo que a especialização não importasse tanto quanto a sensibilidade necessária para a generalização desses mesmos princípios do trabalho do artista para todos os âmbitos de sua existência. A mim também, como para Medina, interessa considerar a arte de modo absolutamente geral, o que exige levar em conta o modo particular como empregamos nosso tempo de vida. Mas se Medina afirmava não fazer filosofia, senão vida, sugerindo uma oposição entre uma coisa e outra, minha proposta nesta pesquisa parte da "descoberta" de que para os românticos, por exemplo, como será visto, filosofia e vida coincidem, justamente na arte. Se arte é filosofia realizada na vida, coincidência entre opostos, como entre o real e o ideal, se quisermos, então o desejo de fusão entre arte e vida deve dar lugar à identificação da porção da (nossa) vida que se encontra distante da arte, para que então sobre ela se intensifiquem os laços com a filosofia. A relevância de algo como a crítica marxista do trabalho para a arte, por exemplo, pode ser considerada nesta chave, uma vez que é interessante, se vamos considerar o emprego de nosso tempo, que ele não ocorra de modo mecânico e instrumental ${ }^{5}$. De todo modo, a prática resultante culmina no desenvolvimento progressivo de espaços de tempo favoráveis a experiências estéticas por esta razão, nada disso tem a ver com utopia, mas com heterotopia ${ }^{6}$.

\section{SaCdE. 2}

Volta.

(sobre o paradoxo de um trabalho escrito no interior de um programa de poéticas visuais)

É prudente avisar meu leitor que esta não é uma dissertação de mestrado comum, nem bem um "livro de artista" em seu sentido mais convencional. Desde o início me recusei ao estreitamento habitual do enfoque de pesquisas acadêmicas e à sua estrutura mais rígida, preferindo, ao invés disso, um certo distanciamento que me permitisse compreender um campo mais amplo e heterogêneo. Para isso, como cheguei a escrever à época da qualificação do presente trabalho, pretendi me valer do lugar desta pesquisa no interior de um programa de Poéticas Visuais

\footnotetext{
${ }^{4}$ Citado por Cristina Freire, em Isidoro Valcárcel Medina no MAC USP p. 18.

${ }^{5}$ Este será um tema tratado mais adiante em minha pesquisa. Por ora, cabe considerar, para sublinhar a coerência do interesse pelo pensamento marxista no interior de nossa proposta, que "o objetivo mais ambicioso, mais difícil e mais longínquo do marxismo é mudar a vida, recriar lucidamente a vida cotidiana. Henri Léfèbvre, 1958.

6 Michel Foucault define heterotopias como "espécies de utopias realizadas". Ver em http://aufklarungsofia.files.wordpress.com/2011/06/outros_espacos.pdf.
} 
para desenvolver as questões de modo um tanto mais livre e flexível que o usual. ${ }^{7}$ Geralmente, as regras e os esquemas que preestabelecem formatos específicos em produções acadêmicas, mantêm a dimensão afetiva de nossas possíveis experiências neste âmbito, restritas a campos bem delimitados e conhecidos, o que na realidade nos parece confortável, pois permite estabelecer critérios que possibilitam assimilação ligeira, julgamentos seguros, e poucas surpresas - algo que está de acordo, certamente, com nossos interesses instrumentais mais habituais.

Cabe reconhecer, contudo, que se minha intenção era romper com a estrutura mais habitual de dissertações acadêmicas, no plano da aparência ao menos, ainda estou muito próximo dela, e se pela própria metodologia empregada, pela estrutura do texto e pela heterogeneidade dos elementos de que se trata, este trabalho não deve ser compreendido como uma dissertação tradicional, por outro lado, não é bem certo também o modo como pode ser compreendido como um trabalho de arte. Esta posição paradoxal, porém, não é acidental. Trata-se, pelo contrário, de uma posição assumida já desde o título desta pesquisa: "arte em suspenso" afirma ao mesmo tempo um estado de arte e de não-arte, podendo tanto significar a arte cessada, suprimida, quanto também o contrário, a conservação da arte numa posição elevada, de modo permanente.

Não interessava, portanto, a esta que fosse compreendida como um trabalho de arte pela afirmação de uma certa distintividade por aspectos puramente visuais. Se de início esta era minha proposta - planejava um trabalho de formato muito pouco convencional -, meus planos mudaram tão logo percebi que a distância que me interessava considerar, entre arte e não arte, não era do tipo que poderia ser propriamente coberta com a aplicação de esquemas gráficos, imagens, cores e texturas - o que talvez garantiria o pertencimento à classe das artes por questões de "semelhança de família", como se costuma dizer a partir de Wittgenstein, mas pouco faria em relação à significação da experiência propriamente dita. A visualidade, ou, de modo mais geral, a sensorialidade, é, com efeito, bastante explorada nas chamadas artes aplicadas, como no design, na publicidade e na moda, sendo, na maior parte dos casos, pela própria limitação de seus interesses,

\footnotetext{
${ }^{7}$ Embora minha banca não tenha reconhecido qualquer relação de continuidade entre meu texto de qualificação e meu trabalho final, naquela ocasião já adiantava: "Linearidade, ordenamento, sistematização e resultados, são noções que não cabem aqui, ao menos não de modo tão literal. Esta pesquisa não pretende fazer frente ao que considera o espírito deste tempo, impondo formas de pensamento pouco compatíveis com nosso modo de vida. Pelo contrário, busca assumir a fragmentação e o gradual desenvolvimento de noções como as de rede e rizoma como algumas das principais características da modernidade e, através de algo como um mapeamento do pensamento, a tendência à substituição de estruturas bem ordenadas por cadeias difusas de elementos mais ou menos heterogêneos. A pesquisa é desenvolvida assim, como se monta um quebra-cabeças, buscando identificar encaixes e imagens que sugiram algum sentido. A principal vantagem deste método de trabalho é sem dúvida a própria constelação que ele permite vislumbrar; no entanto, seu principal inconveniente, ao menos do ponto de vista do mercado e do conhecimento científico, é quanto ao pragmatismo dos resultados da pesquisa realizada nestas condições". Com isso, creio, pretendia dizer que o resultado poderia parecer um tanto intragável para os padrões, e interesses, habituais; algo que, desnecessário dizer, minha banca confirmou habilmente.
} 
afirmativa de discursos de significação bastante restrita - a despeito muitas vezes de suas promessas $^{8}$. Assim, acreditando que a visualidade, ou a atribuição de elementos puramente retinianos e sensuais, como diria Duchamp, não seriam suficientes para ressignificar nossa experiência em relação à não-arte, pensei ser mais coerente com seu reconhecimento, que assumisse, ao invés da visualidade, a própria "teoria", como "não-arte", de modo então a experimentar as consequências formais de seu deslocamento para um contexto "poético". Com isso, contudo, não pretendia que o trabalho perdesse totalmente seus vínculos com pesquisas acadêmicas convencionais, posto que, com todas as desejadas transformações, eram ainda elas, enquanto tais, que me interessavam considerar de modo poético. Isto é, ao tomar um trabalho acadêmico como arte, não me interessava tanto a recusa do desenvolvimento de questões conceituais em nome de um trabalho formal mais superficial, quanto um trabalho sobre a forma da própria elaboração conceitual no contexto acadêmico. No que concerne à arte, a recusa ativa do engessamento habitual do pensamento no contexto acadêmico é muito mais significativa, por sua própria potencialidade crítica e poética, do que um livro que seja apenas para ser visto, e não propriamente lido - o que afirmaria uma oposição de tipo dualista que não me interessava afirmar. Sem a estrutura de dissertações convencionais, nem a aparência mais habitual de um trabalho de arte, este trabalho se tornou, por fim, algo como um corpo estranho, sem um lugar certo, entre uma coisa e outra; entre arte e filosofia; poesia e esquizofrenia.

Naturalmente, minha banca reconheceu a estranheza de minha pesquisa, e demonstrou notável perplexidade em relação a algumas de minhas escolhas. Questionaram, por exemplo, por que, se opto por escrever, ao invés de me aproximar de outros artistas contemporâneos que escrevem, me aproximo de artistas muito distantes de propostas semelhantes às minhas, como Kandinsky, Klee e Francis Bacon. Em relação à heterogeneidade dos elementos de que trato, consideraram, sobretudo, o descabimento de meu projeto de recuperação do pensamento romântico e de noções como as de genialidade, espiritualidade, e estética, num contexto contemporâneo.

Com relação a estas questões, em primeiro lugar, é necessário destacar a posição marginal destes artistas visuais, dentre os quais me incluo, que propõem escritos como trabalhos de arte, em relação à própria arte, em seu sentido mais tradicional. Ainda que possam eventualmente ocupar a maior parte dos espaços institucionais contemporâneos, isto jamais tornará estes trabalhos casos

\footnotetext{
${ }^{8} \mathrm{O}$ apelo sensual da publicidade muitas vezes culmina em representações do que poderia ser considerado versões da noção de experiência estética, particularmente em seu sentido transcendental, como em http://www.youtube.com/watch?v=ovdvUtMxtmc (Gucci); e http://www.youtube.com/watch?v=Dngy-AqPjbo (Lacta)
} 
centrais de arte, pois a própria significação destes trabalhos é dada em relação à tradição de que se distanciam em maior ou menor medida. Em segundo lugar, cabe recordar que considero o projeto de fusão entre arte e vida partindo do pressuposto de que, novamente, "todos somos artistas". Como consequência, entendo que para pensar e fazer arte não preciso me pautar pela classe reconhecida, pois, como também dizia Duchamp, tenho minhas dúvidas a respeito do valor dos julgamentos que reconhecem e legitimam certos artistas em detrimento de outros. Se todos somos artistas, me interessa muito mais levar em conta aqueles que estamos habitualmente acostumados a considerar não-artistas, os quais estão muito mais à margem do campo da arte tradicional, do que estes outros artistas que, mesmo com produções muito pouco convencionais ou, de modo mais específico, mesmo escrevendo, são reconhecidos e legitimados. Assim, se retomo o projeto de fusão entre arte e vida, e, na "vida", considero não artistas, não me parece tão interessante adotar como referência na arte exemplos também marginais, como que para aproximar as margens das margens. Antes, considero em arte casos centrais, para então aproximar as margens do centro - daí minha opção por pintores, no lugar de artistas conceituais; e daí também meu interesse em relação a elementos centrais da tradição moderna, como a estética e a genialidade.

Vale destacar, para evitar mal-entendidos, que ao afirmar a centralidade de noções como estética e genialidade, não ignoro o nível em que se dá a recusa histórica destes termos pelas vanguardas modernas. Que a noção de experiência estética, por exemplo, tradicionalmente propiciada pelo trabalho do gênio, seja central, não decorre que seja elemento necessário ou suficiente para que algo seja arte. É, aliás, por esta centralidade que alguns de nossos artistas recentes mais interessantes são considerados marginais. A crítica e, em particular, a ironia em relação ao centro, ou ao que se espera verificar no centro, tem, na maior parte das vezes, o sentido de questionar e ampliar a esfera da arte, incluindo as margens e reduzindo as distâncias entre arte e não-arte. Além disso, estas noções que estão no centro, não permanecem aí inalteradas. Como sugere Helio Oiticica quando considera "que a vida em si mesma é o seguimento de toda experiência estética" ${ }^{9}$, muito mais interessante do que refutar em definitivo estas noções que nos parecem problemáticas, é experimentar modificar seus sentidos mais habituais, e estender seus usos.

SaCdE.3

(A estética revisitada)

\footnotetext{
${ }^{9}$ Citado em Katia Maciel, "O cinema tem que virar instrumento," in Seguindo Fios Soltos: caminhos na pesquisa sobre Hélio Oiticica (org.) Paula Braga, edição especial da Revista do Fórum Permanente (ed.) Martin Grossmann.
} 
A estética, como nos interessa aqui, compreende o meio sensível em que nos encontramos como que imersos a partir de nossa situação corpórea no espaço num dado momento. Neste instante, por exemplo, podemos considerar toda a espacialidade ao nosso redor, assim como, no caso mais específico deste trabalho, o desenho destas letras, a pigmentação da tinta e o contraste da massa de texto em relação ao suporte, estas páginas brancas e opacas. São as qualidades estéticas deste trabalho que o tornam uma "coisa", para dizer como Paul Valéry, identificável no interior de uma dimensão comum de nossa existência. Aí, por estas suas propriedades estéticas, esta "coisa" posta no mundo preserva características de uma condição sensível específica, já que torna-se imediatamente registro (monumento) de um período histórico que jamais poderá ser recuperado daí o interesse histórico pela arte e, em particular, pelas artes visuais, pela própria consistência material relativamente permanente das produções que tradicionalmente cabem nesta categoria. Isto serve, contudo, tanto para produções que compreendem dimensões subjetivas mais específicas, quanto para produções industriais, realizadas em série. Em qualquer caso, como uma dessas garrafas com escritos que algumas pessoas lançam ao mar e que normalmente apenas muito tempo depois são encontradas, esta materialidade, em certa medida, estável, possibilita espécies de encontros no tempo que permitem reconhecer diferenças e, se estamos abertos, operar diálogos e negociações; o que deve contribuir para o desenvolvimento de nossa consciência humana. Geralmente, em nossas relações cotidianas, trabalhamos com níveis muito superficiais de nossa consciência porque agimos, de acordo com interesses individuais, de modo automático e muito pouco refletido; quando, porém, nossas intenções não são mecânicas, nem envolvem os interesses mais habituais, mas, pelo contrário, ambicionam atingir outras esferas, temos a possibilidade de agir de modo mais consciente, programado, conjunto, e, talvez, profundo.

A estética, porém, não interessa apenas por compreender nosso plano comum de pertencimento ao mundo, o plano físico em que se dá toda sorte de relações por intermédio de nossos sentidos, mas, especialmente, pela indeterminação da experiência que nomeia ${ }^{10}$. Com isso, quero dizer que não interessa tanto que não haja consenso com respeito ao sentido mais exato da natureza transformadora da experiência estética, quanto o fato, por si só significativo, de que seus sentidos, nos casos particulares em que estas experiências se efetivam, sejam considerados e discutidos. Que a experiência estética não possa ser julgada totalmente compreendida resulta que

\footnotetext{
${ }^{10}$ Como considera Thierry de Duve, de modo bastante pessoal: "Interesso-me apenas por obras que não entendo. E a sensação de não entender uma obra não é suficiente; o que importa para mim é uma certa quantidade de enigma, de perplexidade que coloca o intelecto em movimento. Para mim é mesmo a experiência estética que valorizo, o que me faz seguir, é a sensação de que a obra contém conhecimento que desconheço". Thierry de duve (em artigo na revista Concinnitas, vol. 7, 2004). Também Duchamp sugere que o prazer venha de certa incompreensão, como diz, em relação à Mallarmé: "Como ainda não o compreendo completamente, tenho muito prazer lendo-o, do ponto de vista da sonoridade, da poesia audível" P. 177.
} 
os objetos em relação aos quais ela se dá possam ser muito mais contemplados e admirados, e muito menos instrumentalizados. Isto é, "a sensação de que a obra contém conhecimento" que se desconhece, é contrária ao modo habitual de tomar as coisas "já conhecidas" no mundo, porque sugere a impossibilidade de fechamento da experiência, e, por conseguinte, reduz as possibilidades de instrumentalização de seus objetos. Enquanto os sentidos da experiência permanecem em aberto, então ela tem uma "finalidade sem fim" em si, e pode ser apreciada continuamente - daí que algumas obras de arte sejam consideradas inesgotáveis. O resultado é uma espécie de libertação de nossa experiência no mundo.

Quando se insiste no caráter a uma só vez político e espiritual do que se considera a "revolução" estética, isso nos dá uma ideia do que se acredita serem as dimensões de suas consequências. Enquanto politicamente seu interesse nos parece óbvio, pela própria desinstrumentalização de nossa experiência cotidiana, espiritualmente ela nos parece oculta, algo como uma sugestão de mágica. O termo "espiritual", contudo, pretende, grosso modo, referir-se à sensação de plenitude resultante daquele aspecto "totalizante" da experiência estética, uma vez que ela resulta da identificação de um fim no que é habitualmente tomado como meio, o que, por sua vez, se relaciona à suspensão da oposição habitual entre elementos como sujeito e objeto. Nesta pesquisa me refiro a uma citação de Klee para tornar este sentido menos abstrato, mas penso que muitos outros exemplos poderiam ser considerados, como quando um músico revela a sensação de fusão entre corpo, instrumento e som. Que este estado possa eventualmente ser explicado cientificamente, pela consideração dos efeitos da liberação de certos hormônios, por exemplo, em nada reduz, a meu ver, sua significação superior, pois, não só o Espírito, sendo Absoluto, inclui todas as coisas, inclusive a matéria, como, independente disso, este fenômeno aponta para a possibilidade de superação definitiva de um estado, identificado com o fenômeno da fragmentação durante a modernidade, que, considerado um "mal”, causa mal-estar e sofrimento.

Ainda mais refutada do que a noção de espiritualidade em arte, é a de genialidade. Para tratar da questão, meu guia principal foi um estudo bastante original de Márcio Suzuki, professor de filosofia da Universidade de São Paulo, intitulado $O$ Gênio Romântico. Embora com foco no estudo de autores do século XVIII, o livro de Suzuki oferece um panorama bastante geral do que seja a genialidade, e segundo a minha leitura, as coordenadas para reabilitá-la, num sentido, claramente, muito diverso do estereotipo mais usual.

De acordo com as raízes da tradição moderna, a experiência estética é algo que só pode ser experimentado em nossa relação com a natureza, ou, em relação com o trabalho do gênio, através de quem ela age livremente. Tradicionalmente, pensa-se que essa espécie de conexão profunda e direta com a natureza seja algo muito raro, de modo então que a ideia de gênio marcaria o ápice da 
distinção do artista em relação ao não-artista. Curiosamente, porém, no berço da formação do conceito, está presente a ideia de que o gênio não é outra coisa que Espírito, e que, assim, todo serhumano é gênio, ou ao menos tem em si o gênio, em germe, a ser desenvolvido.

Antes, se considerarmos o gênio (gênio do gênio, como ensina Suzuki) como sendo aquele que eleva, mediante o trabalho, a si mesmo a aos outros ao chamado ponto de vista transcendental, neste plano, que é o próprio plano espiritual, o que ocorre é uma espécie de nivelamento. Pois se admitimos que a experiência estética se define pela suspensão de oposições, a parte do público que vive a experiência estética ascende, e é então posta num plano no qual pode-se considerar que tenha a própria genialidade desperta, momento, então, em que é também artista ${ }^{11}$.

Se considerarmos em relação a isso o que nos propõe Thierry de Duve, que somos todos artistas, assim como o projeto de fusão entre arte e vida, consideramos a possibilidade de nossa permanência definitiva neste estado estético, o que nos permitiria então experimentar "a vida em si mesma", como dizia Oiticica. É claro que o que propõe de Duve se aplica apenas após Duchamp, particularmente após seus ready-mades, e se algo como a noção de experiência estética pode ser admitido a partir de então, é um pré-requisito necessário que seu sentido possa ser considerado em relação às obras deste artista; algo que pode ser obtido, a meu ver, adotando como o cerne da experiência estética, como propomos, a própria indeterminação da experiência. Em outras palavras, teríamos de considerar a possibilidade de manter com o mundo, de modo geral, um "livre juízo reflexivo". Em se tratando de arte, porém, para além da atitude contemplativa, interessa de modo particular a ação, ou aquilo que se propõe "na prática" a partir daí, pois a ação que resulta de nosso livre juízo reflexivo, é a ação que sintetiza, em certa medida, a potência individual do artista. Neste sentindo, o despertar definitivo do gênio exige considerar as condições sensíveis, referentes ao tempo e ao espaço, que permitem a um indivíduo o exercício de suas potências individuais.

De modo geral, este projeto encontra afinidades com filosofias tão diversas quanto as de Schiller, Schlegel, Nietzsche, Foucault, e mesmo Marx, no princípio de seu pensamento ${ }^{12}$. Não nos interessa por ora analisar a diferença das formas como se pensa que essa potencialidade pode ser

\footnotetext{
${ }^{11}$ A este respeito, Duchamp chega a considerar que "os espectadores é que criam os quadros". Citado em Formas de vida. Nicolas Bourriaud, p. 185. Thierry de Duve, de modo semelhante, considera que "apreciar é fazer". Em Kant after Duchamp.

${ }^{12}$ Schiller foi importante influência para os românticos, como Schlegel, e mestre de Nietzsche. Foucault, por sua vez, é discípulo de Nietzsche, enquanto as bases românticas do pensamento do jovem Marx são bastante conhecidas (ver, por exemplo, Romantismo e Política, de Michel Löwy). Com isso, não pretendo afirmar que pertencem a uma mesma tradição, visto que há, claramente, particularidades inegáveis em cada caso, mas sim que há uma raíz comum de identificação possível. Com efeito, é notável a percepção de traços comuns, particularmente relacionados ao reconhecimento de uma certa potência do indivíduo, e à arte.
} 
desenvolvida em cada caso, e em que medida, mas sim que, de modo mais ou menos declarado, em todo caso, ela culmina com a realização da arte na vida. Não por acaso este ponto remete, geralmente, aos pré-socráticos, onde o sentimento espiritual de totalidade se faz presente com mais clara evidência, particularmente, no próprio modo de vida comunitário do grego antigo. Sublinhar a pertinência da recuperação deste amplo projeto filosófico no interior da prática artística contemporânea é parte do intuito deste trabalho.

É inegável, pois, ainda que se questione e relativize a autonomia da arte, que o artista goze, no exercício de seu trabalho, de uma liberdade muito pouco comum a trabalhadores de outras áreas. Assim, se considero, aproximando, talvez, Thierry de Duve a Mário Pedrosa, que todos ao longo de suas vidas são artistas, cabe considerar as condições reais de possibilidade de efetivação de algo como um "exercício experimental da liberdade" em cada caso particular. Isto deve nos permitir considerar se nos interessa afirmar a distintividade tradicional do artista reconhecido, ou se, na medida em que neste momento temos a oportunidade de tornar esta distinção histórica consciente, nos utilizamos dela para atuar em direção contrária. É certamente o caso de artistas como Lygia Clark, que, de modo particularmente ativo, não se contenta com a recusa do lugar tradicional do artista, revelando o desejo de "Liberar a criatividade geral de todos, sem quaisquer limites psicológicos ou sociais." ${ }^{13}$ De modo mais geral, podemos levar em conta o interesse poético de esforços, os mais diversos, que tenham o sentido de ampliar a liberdade, recompondo condições sensíveis e transformando vidas, de modo então a favorecer aquelas significativas experiências que, de acordo com a tradição, definem o gênio. Neste sentido, esta pesquisa me permite hoje considerar o valor poético da organização de movimentos sociais; de reformas institucionais; e de ações individuais isoladas.

$\mathrm{SaCdE}-4$

(...)

Não estou bem certo da medida em que isto pode interessar a meu leitor, mas minha defesa não foi exatamente o que se poderia considerar uma "experiência satisfatória". Eu, de todo modo, tenho muito a agradecer pela forma muito sincera como minha banca recebeu algumas de minhas ideias, e não recebeu outras, pois, ainda que de modo conflitivo, deixaram bastante evidente pra mim, que sou um iniciante confesso, a posição "douta" da academia, assim como o plano a partir de onde falam alguns de meus interlocutores no chamado "mundo da arte", mundo ao qual recomendaram minha conformação.

\footnotetext{
${ }^{13}$ Lygia Clark. “L’Homme, Structure vivant d'une architecture biologique ET cellulaire”. Data não identificada.
} 
No mundo que me interessa considerar, porém, a arte não constitui um território à parte. Já por esta pequena discordância, creio, o desacerto de minhas propostas em relação ao pensamento de meus avaliadores se explica.

Em relação a isso, no dia de minha defesa, enquanto esperávamos a banca dar o veredicto de minha aprovação ou reprovação, meu irmão, então presente, me lembrou de Fritjof Capra. Para ele, a crise entre mim e minha banca devia-se ao fato de que partíamos de "paradigmas" distintos, eles de um supostamente "cartesiano", eu de um "holístico". Não havia pensado nas coisas dessa forma, mas devo dizer que sua argumentação fez sentido. Mais tarde, ele me presenteou com $O$ Tao da Física, livro escrito durante os anos 70. Já na introdução, para minha surpresa, reconheci afinidades inegáveis relativas ao "método", por assim dizer: Capra revela ter feito uso de "plantas de poder" para levar a cabo seu projeto "holístico" de articular aspectos do pensamento ocidental ao oriental. Em que pese as diferenças entre o projeto daquele autor e o meu, muito mais modesto, o sentimento vívido de profunda integração, e de pertencimento a uma totalidade absoluta despertado pelo consumo de um chá como o da Ayahuasca, foi também decisivo para mim. Talvez até o grande elemento encorajador de meu método pouco usual de pesquisa. Significativamente, em relação a isso, também algumas críticas ao trabalho de Capra se referem ao caráter "confuso" de sua proposta. Se isso pode ser considerado algo como um "efeito" do uso do chá, deixo a cargo do leitor considerar em relação a quê este elemento é positivo, ou negativo. Certamente, para os padrões habituais da academia, é negativo, mas nos interessa afirmá-lo?

É claro que pelas próprias características da modernidade, há em nosso tempo forte rejeição em relação à métodos e propostas que pretendam a rearticulação de questões que se acham distanciadas, como que por uma exigência interna de progresso especializado - tanto pior se com isso for afirmada ainda a dimensão espiritual destas ideias, e mesmo sua afinidade com algo como um pensamento religioso, como a certa altura chega-se a afirmar aqui. Tal como entendo, porém, é a própria fragmentação da subjetividade moderna que torna possível a identificação naturalizada do mundo em fragmentos igualmente desconexos, e o estranhamento em relação a ideias que evoquem certa noção de reintegração e completude. Pela relevância destas ideias, é minha convicção que a instituição "arte" ainda é o meio mais propício para abriga-las - não talvez por ser o meio mais respeitável, com tudo o que - ora muito inteligentemente, ora não tanto - foi e tem sido feito, mas certamente por ser aquele em que podemos ser (ainda mais verdadeiramente) livres.

É certo que entendo que o que digo parece um tanto abstrato e restrito a um plano puramente conceitual, e que o meio artístico está especialmente interessado no que estas ideias resultam na prática. Justamente. Garanto a meu leitor, incrédulo ou não, que estas ideias vem se 
desenvolvendo em minha prática, e é por isso, inclusive, que considero tornar pública a experiência de minha defesa. Se nosso intuito é, grosso modo, tornar a vida uma experiência significativa e satisfatória, e me encontro agora em um ambiente acadêmico, cabe reconhecer que poucos, dentre todas as pessoas que conheci neste âmbito durante este período, estão bem satisfeitos com as limitações habituais aí impostas - embora elas sejam, paradoxalmente, normalizadas por nós mesmos. É necessário criar um estranhamento em relação ao que nos parece banal, para denunciar um estado de coisas que talvez possa vir a ser diferente, como em certa medida, esta pesquisa procurou ser.

De resto, não julgo de tanto interesse trazer questões referentes à minha prática cotidiana para cá, embora elas estejam diretamente relacionadas ao modo um tanto nômade como vivo neste momento, em grande medida porque entendo que já tivemos o suficiente de certo tipo de ironia em relação a este tipo de ideias, e porque tenho em conta o que adverte Clarissa Diniz quando considera, citando Nikos Papastergiadis, que "aproximar arte e vida (...) pode também levar à idiotice e à banalidade de a vida ser reproduzida em nome da arte ${ }^{14}$. Não me interessa claramente que a vida seja meramente "reproduzida em nome da arte", mas, com tudo o que foi dito, interessa certamente verificar as consequências de tomar a vida como uma experiência aberta à transformação, como se toma a arte. Embora isso pareça simples, e na realidade acredito que seja, penso compreender o sentido de que se considere a partir disso uma verdadeira "revolução espiritual". Por isso me dou o tempo necessário para que estas ideias se desenvolvam de modo a fazer justiça à potência que sei possuírem - se a ironia então se preserva, ao menos isso não ocorre do modo mais habitual em arte, desde Duchamp. Estes pensamentos, de qualquer modo, me parecem suficientemente consistentes para caberem aqui, senão de modo definitivo, ao menos para serem discutidos - talvez não num contexto propriamente acadêmico, agora que esta etapa se encerra, mas, quem sabe, numa casa aberta qualquer, com vinho, cerveja e música, onde então algo como um projeto de curadoria compatível com estas ideias pode ser considerado. ${ }^{15}$

\footnotetext{
${ }^{14}$ Clarissa Diniz. Partilha da Crise: ideologia e idealismos.

${ }^{15}$ Este deve ser meu projeto de doutorado. "Casa Aberta" é nome de uma ocupação ocorrida em São Paulo no ano de 2009 que me serve de referência. Para desenvolver estas ideias, adianto meu desejo de estabelecer algo como uma rede, e aproveito a oportunidade para propor a meu leitor ou leitora, caso haja interesse, que entre em contato comigo, por Facebook, onde posso ser encontrado por meu próprio nome, ou por email: lucas.jarasoares@gmail.com.
} 
"E, assim, talvez o mais belo continue a se dar na escuridão, afundando, apenas nascido, na noite eterna-ou seja, o espetáculo daquela força que um gênio não emprega 'em obras', mas 'em si como obra', isto é, na sua própria dominação, na depuração de sua fantasia, na escolha e ordenação do afluxo de tarefas e ideias".

Friedrich Nietzsche 


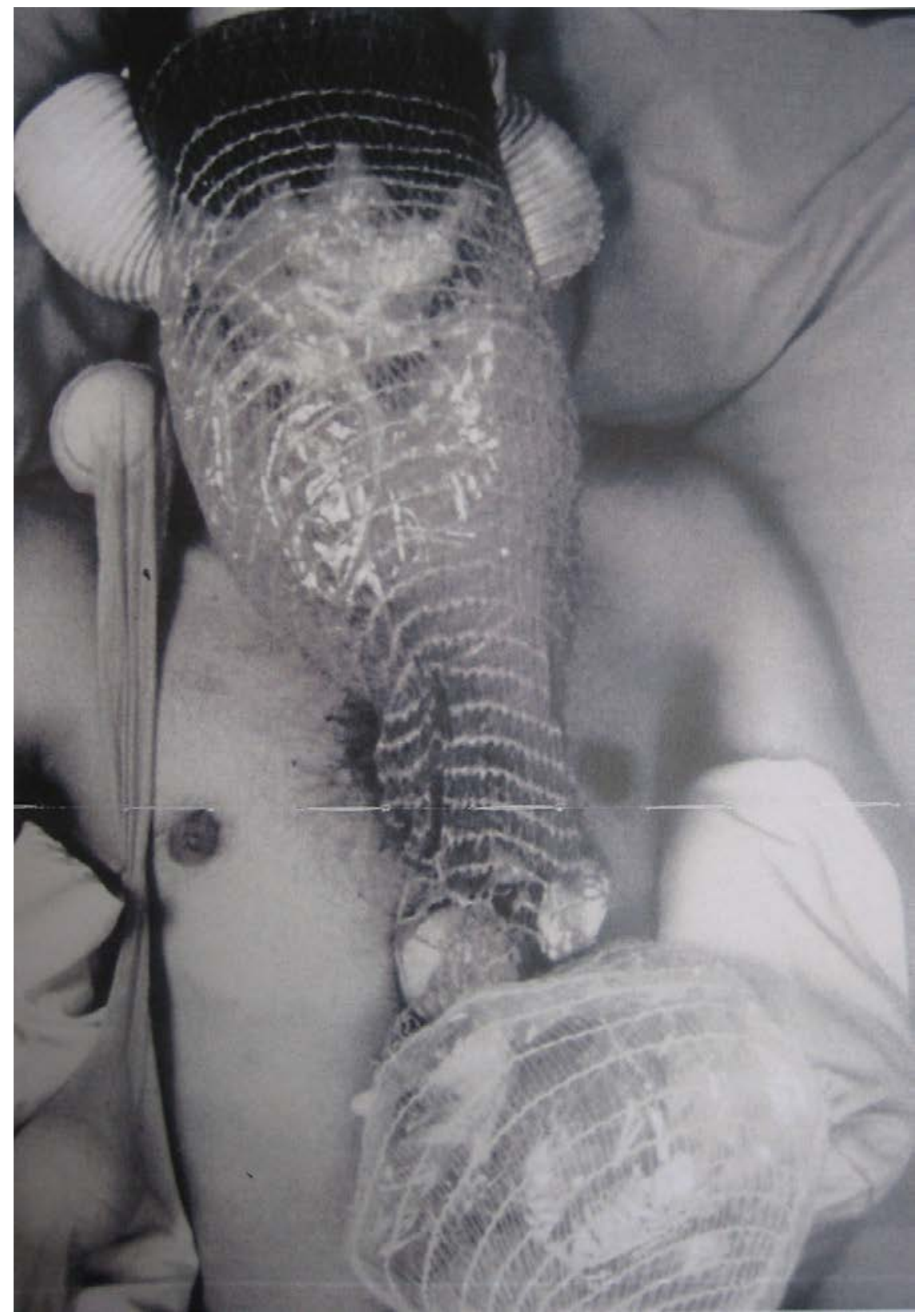

Lygia Clark. A estruturação do Self (1976-1988) 


\section{Prelúdio}

A presente pesquisa tem como pano de fundo, a recuperação do projeto de fusão entre arte e vida, e a consideração de algumas de suas possíveis implicações mais drásticas. Como uma estratégia na direção da realização deste projeto, nosso ponto de partida é uma reflexão acerca do problema da consciência em arte, ou, mais especificamente, acerca do problema da busca do artista por tornar-se criticamente consciente da dimensão discursiva de suas produções. Antes, para aclarar por que a consciência da dimensão discursiva de um trabalho em arte constituiria um "problema", trata-se de retomar aqueles elementos que na arte não se deixam subsumir por conceitos, elementos relacionados ao potencial transformador da arte - precisamente o que define seu potencial espiritual $^{16}$ - de modo a considerar então a relação entre discurso consciente, e aquilo que a arte tem de "indizível".

De início, podemos considerar que a consciência está presente, ainda que minimamente, ao longo de todo o desenvolvimento da arte ao longo da história. O próprio movimento que a história da arte sugere, das pinturas em cavernas, aos afrescos, às pinturas em telas, à fotografia, e ao vídeo, por exemplo, revela, antes do esforço de uma construção artificial, a posteriori, o desejo individual “de abarcar campos cada vez mais vastos, na apreensão sensorial, e também substantiva, do mundo ou do universo", de modo então a alargar o campo da experiência estética para além de suas limitações históricas. ${ }^{17}$ Claramente, isto pressupõe, no momento mesmo de realização das obras, o mínimo reconhecimento de quais sejam as limitações destes campos a ampliar. De modo muito geral, até muito recentemente, a consciência de trabalhar junto a estas limitações era possivelmente "natural", uma vez que o artista via-se muito logicamente identificado em relação a outros que atuam e atuaram, como ele, no mesmo meio, pintura sobre tela, por exemplo, o que certamente contava como estímulo para que colocasse à prova a própria capacidade criativa, no sentido de fazer naquele meio específico o que nunca houvesse sido feito. Isto é, a delimitação de seu lugar de atuação e a ideia de estar ciente das máximas realizações já alcançadas num determinado meio, seriam estímulos para fazer "ultrapassagens" num âmbito comum, o que por fim favoreceria a

\footnotetext{
${ }^{16}$ Como um recurso experimental relativo ao desenvolvimento desta pesquisa, algumas notas remetem a páginas finais deste volume, onde são levantados alguns pontos muito gerais relativos às questões assinaladas. É lícito que a leitura se desenvolva de modo não linear. Ver, por exemplo, a respeito da questão da espiritualidade a nota sobre espiritualidade, na p. 70.

${ }^{17}$ A citação completa diz: "No mundo aberto de hoje, trata-se, ainda, e no fundo, de absorver, de abarcar campos cada vez mais vastos, na apreensão sensorial, e também substantiva, do mundo ou do universo, o que, afinal, desde a arte das cavernas, foi sempre a grande missão civilizadora da Arte". Mário Pedrosa, Mundo em crise, homem em crise, arte em crise, em Mundo, homem, arte em crise, p. 219.
} 
constituição de uma história. A consciência de atuar nos limites deste campo comum revela-se fundamental, porém, não apenas para assegurar ao artista o sentimento de pertencimento a uma história ou à tradição de uma prática específica, mas porque deve-se a esta sua posição - porque o que está para além deste campo conhecido não se sabe -, os sentidos daquilo que escapa ao controle, e assim, aquele "coeficiente artístico" que permanece inconsciente em toda produção. ${ }^{18} \mathrm{Se}$ a transformação prometida pela arte pressupõe um movimento na direção do desconhecido, então o trabalho sobre esta espécie de fronteira, entre o campo conhecido, consciente e comum, e o campo desconhecido, inconsciente (e também comum), seria a condição que possibilitaria não apenas pensar a arte como uma prática espiritual, mas vincular esta prática a um desenvolvimento humano mais amplo, no sentido social e histórico. À perda gradual do sentimento de pertencimento a um campo comum, corresponde a diminuição do interesse histórico e social sobre o "coeficiente artístico" de uma dada obra, pois então aquilo que permanece inconsciente e desconhecido ao artista, passa a interessar a poucos além dele.

Se é verdade, porém, que a consciência de pertencimento a um campo comum sempre foi fundamental para as transformações que a arte operou ao longo da história, podemos considerar, com alguma segurança, que a consciência passa a constituir um problema para o artista quando, pelo próprio desenvolvimento da crítica durante a modernidade, perde-se a segurança de pertencimento a um campo comum. Quando a singularidade da ideia de história se revela uma ilusão, percebe-se que as transformações já não podem ocorrer no sentido em que se davam desde a modernidade, pois as possibilidades de sentidos tornam-se múltiplas e incertas. Com efeito, embora o artista contemporâneo ainda reconheça a si mesmo em relação àquela história, ele encontra-se agora do lado de fora dela, para além das margens.

A não limitação aparente da arte contemporânea indica a coincidência entre os limites da arte e os limites da vida - o que não significa que ela tenha encontrado seu fim ou a morte, mas simplesmente um campo muito mais vasto. Se, como se diz, "qualquer coisa" pode agora ser arte, o que em certa medida pulveriza a ideia de um meio comum de atuação, o desafio que nos interessa considerar é a possibilidade de evitar com isso a perda daquela dimensão transcendental que a autonomia da arte pretendeu resguardar durante a modernidade. Na esteira de Duchamp, a partir

\footnotetext{
${ }^{18}$ A noção de "coeficiente artístico" é proposta por Marcel Duchamp, em O ato Criador. O artista a define como "uma diferença entre a intenção e a sua realização", ou ainda "como (...) uma relação aritmética entre o que permanece inexpresso embora intencionado, e o que é expresso não-intencionalmente". Sua aplicação para além do campo artístico pode ser pensada se assumirmos o termo arte em seu sentido antigo, como um "fazer". Um paralelo bastante claro com a noção de coeficiente artístico pode por exemplo ser pensado na filosofia, com a ideia de "chiste involuntário" desenvolvida a partir de Kant no idealismo alemão. Ver O Gênio Romântico. Márcio Suzuki, p. 226.
} 
de quem, como considera Thierry de Duve, todos somos artistas ${ }^{19}$, o que a consciência sobre o plano sensível e a consequente aproximação da filosofia permitem, é o reconhecimento da potência da arte e, se quisermos, daquela sua característica dimensão espiritual, em todo o plano estético da existência. Esta amplitude, no entanto, de nada vale se a partir dela novas narrativas não puderem ser estabelecidas, e com elas, novos limites sobre os quais operar. Não se trata, portanto, de destacar o fim de uma ideia singular de história, o lugar pós-histórico da produção atual, e com ele o luto, a decadência, a impotência, a banalização, a nostalgia, o mal-estar e tudo mais o que tem sido comum desde pelo menos os anos 60; ou, inversamente, de celebrar a liberdade de um período que teria toda a história à disposição para livre uso. 0 desligamento entre arte e história traduz a falta de perspectivas que ocasiona, em primeiro lugar, a "compreensão" de sua dimensão espiritual, ou de sua potência de transformação, então posta a serviço de interesses em grande medida limitados a universos particulares; e em segundo lugar, a desorganização e rarefação do meio artístico que se mostra, junto a uma tendência individualista própria à época, incapaz de elaborar e acreditar em projetos comuns mais amplos. Embora seja um tema sabidamente controverso, penso que a autonomia da arte seja ainda condição necessária para a elaboração de movimentos de resistência ao atual estado de coisas $^{20}$.

A este respeito, vale considerar, a relativa autonomia da arte não é uma questão puramente retórica, pois é, em certa medida, o que possibilita a existência de um programa de mestrado como este, e uma pesquisa como esta. É pela exploração desta autonomia que este trabalho resiste ao imperativo habitual de produção a todo custo, e se apresenta como pesquisa/processo que aposta na importância do desenvolvimento do pensamento crítico para o resgate dos vínculos mais profundos da arte com as novas histórias então em construção. Não seria exagero considerar a partir daí que a pesquisa tem como objeto de interesse indireto a investigação de seu próprio cabimento, como produção aparentemente "teórica", em um programa de poéticas visuais. Esta inserção estratégica da teoria no campo da prática tem em vista, afinal, um objeto muito mais amplo, que requer elaboração e programação. Ao considerar o projeto de fusão entre arte e vida, não se pretende compreender a "vida" de maneira episódica, como geralmente ela se apresenta, recortada e espetacularizada, dentro de molduras institucionais, mas sim a vida mesma, isto é, a totalidade de sua duração individual.

\footnotetext{
${ }^{19}$ Thierry de Duve. "Kant depois de Duchamp". Revista do Mestrado em História da Arte EBA - UFRJ, 1998.

${ }^{20}$ Ver nota sobre a autonomia da arte, neste volume. p.63.
} 
Se meu leitor considera o problema de programações e elaborações teóricas que permitam, em seguida, "simplesmente agir", acreditando que isto significaria a perda justamente do que há de mais precioso em matéria de arte - sua qualidade espontânea, não projetada, indizível e inconsciente, relativa ao chamado coeficiente artístico -, retornamos ao tema da presente pesquisa.

No fim, trata-se de reconhecer, junto a Foucault, a importância de saber a que se presta nossa prática, para se possível resgatar os vínculos de nossa própria existência com sentidos mais profundos, lembrando, porém, que os sentidos de nossas práticas nunca serão totalmente conhecidos. É, afinal, neste jogo que se estabelece entre os dois lados, entre o que se sabe e o que não se sabe, que a possibilidade de transformação do sujeito pela arte se potencializa.

Meu tratamento dos temas no que se segue não quer ser "especializado", no sentido de restrito a um campo específico do conhecimento. Ao invés disso, minha abordagem é propositadamente generalista e, no limite, tem o intuito de possibilitar a elaboração de uma espécie de sistema que permita compreender com maior clareza possível alguns dos sentidos que penso estarem presentes em meu trabalho, ainda que de modo indireto. Nesse sentido, toda a pesquisa é marcada pelo exame de algumas de minhas contradições, como meu gosto por alguns elementos da tradição romântica, e mesmo, talvez, metafísica, e ao mesmo tempo, meu interesse por questões de cunho mais acentuadamente político e social. Foi, de certo modo, a busca por "termos conciliatórios" que permitissem aproximações de opostos aparentes o que me conduziu a noções como a de espiritualidade.

A pesquisa, enfim, está dividida em duas partes principais. A primeira delas sugere as duas tendências opostas aqui já adiantadas - consciência e inconsciência -, e busca considerar os fundamentos do lado que compreende a arte como um trabalho mais subjetivista e menos consciente, visando uma aproximação gradual daquela corrente oposta, mais consciente, através da filosofia, particularmente através da ideia de genialidade. Na segunda parte, busca-se considerar as consequências do projeto de recuperação de alguns elementos do pensamento do idealismo alemão acerca da arte, numa reflexão que considera a possibilidade de estender o ideal de experiência estética para a vida. 
o que está em questão é mais do que a arte enquanto ícone. O que é contestado é a noção racionalista segundo a qual a arte é um gênero de atividade que resulta num produto acabado [...] o que a arte tem hoje à disposição é um material evolutivo que não precisa necessariamente acabar por estar fixado no tempo e no espaço. A ideia de que uma obra é um processo irreversível que alcança sua conclusão num objeto icônico estático já não é de atualidade.

Robert Morris 


\section{Parte 1}

\section{Aproximações da filosofia}

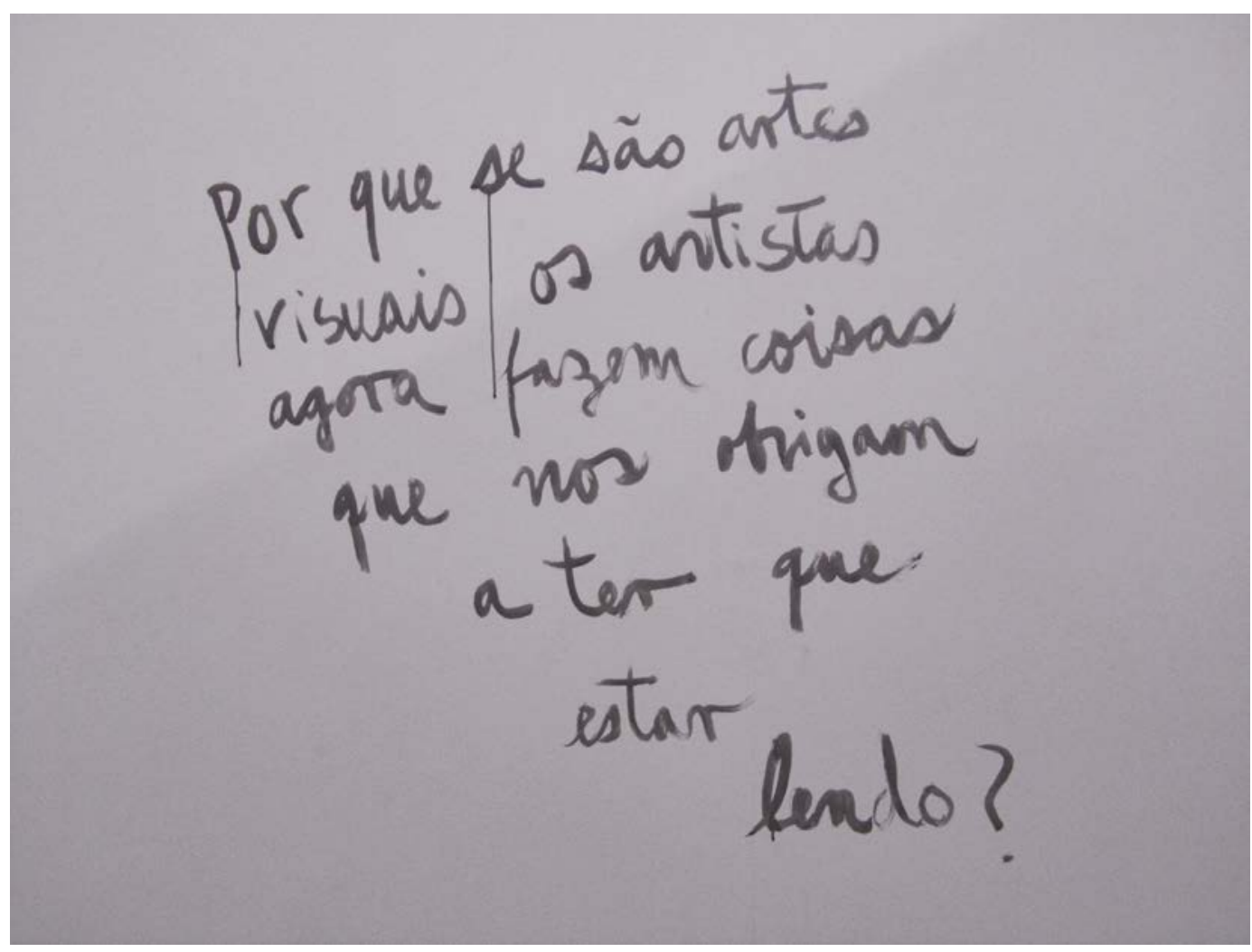

PPPP (Productos Peruanos para pensar), Alberto Cassari.

O questionamento lançado pelo coletivo peruano PPPP na trigésima Bienal de São Paulo, em 2012, sugere um tipo de perplexidade que muitas vezes acende discussões bastante significativas em arte, particularmente porque tende a colocar em evidência a oposição de dois grandes grupos. De um lado, artistas que geralmente compreendem o campo de trabalho no plano mais restrito da visualidade, os quais poderíamos considerar mais tradicionalistas, no sentido de que menos receptivos à abertura do campo da arte; e de outro, artistas geralmente considerados "conceitualistas", os quais seriam mais receptivos à abertura do campo e propensos à experimentação em âmbitos como o da linguagem. Dentre os primeiros, me interessa considerar os que destacam, contrários aos segundos, noções como as de imediatez, intuição, instintividade, espontaneidade, acaso, imprevisto, inconsciente, e mesmo "irracionalidade"; dentre os segundos, inversamente, os que dão maior ênfase à dimensão conceitual, à crítica consciente, à objetividade, 
ao cálculo, à programação - à "ideia" num âmbito mais propriamente racional e discursivo. Não se trata evidentemente de negar possibilidades de conciliamento, que certamente existem, entre um lado e outro. Antes, trata-se de reconhecer, para fins esquemáticos, os casos em que a incompatibilidade se apresenta - tanto no plano metodológico, da prática mesma dos artistas, quanto no plano discursivo -, para buscar identificar os fundamentos - e os possíveis preconceitos que definem a tomada de posições neste embate. Pois se aquela perplexidade em todo caso subsiste, então o que exatamente a sustenta? Haveria alguma espécie de fundamento comum entre quem de um lado espera que o artista se mantenha restrito ao campo da visualidade, e de outro, o artista visual que escreve? A despeito da diversidade de referências possíveis e do habitual relativismo contemporâneo, na raíz deste antagonismo sobrevive um dualismo muito comum, dualismo que a presente consideração pretende colocar em diálogo, para quem sabe uni-las num âmbito mais profundo. 
“...o trabalho do artista, mesmo na sua parte mental, não pode se reduzir às operações de um pensamento determinante. De uma parte a matéria, os meios, o instante, e uma porção de acidentes ( os quais caracteriza o real, ao menos para aquele que não é filósofo) introduzem na fabricação de uma obra uma quantidade de condições que não somente introduzem o imprevisto e o indeterminado no drama da criação, como tendem a torna-la racionalmente inconcebivel, uma vez que a inserem no domínio das coisas, pois ela se torna uma coisa, de modo que o pensamento se torna sensível. [...] O artista não pode abrir mão de um sentimento arbitrário. Ele procede do arbitrário em direção à uma necessidade, e de certa desordem em direção a uma certa ordem..."

Paul Valéry 
...que o artista (...) deixe de ser artista: livre-se do mito de "ser criador" - posição que Ihe assegura uma situação confortável mas inútil - e pense em si mesmo como alguém que está amplamente comprometido com os sistemas e processos de significação em curso na sociedade.

Ronaldo Brito 
1.0 Questão de consciência e inconsciência

O reconhecimento histórico do caráter condicionado de nossa liberdade é certamente o maior responsável pelo ceticismo em relação a noções como instinto ou espontaneidade em nossos dias. Desde pelo menos o século XIX há inúmeras correntes de pensamento que destacam a relativa determinação do homem por estruturas culturais, sociais ou psicológicas, ou que se utilizam de certa concepção de história para pensar o âmbito sócio-econômico como fundamento do homem, mesmo em suas dimensões mais particulares. O pensador marxista italiano Antonio Gramsci, por exemplo, relacionava a espontaneidade com o "senso comum", com uma concepção tradicional e popular do mundo, e com uma característica "das classes subalternas." Em sua visão, a espontaneidade se relaciona ao que "muito vulgarmente se chama instinto", o que "não é senão uma aquisição [...], só que primitiva e elementar" ${ }^{21}$. Reconhecendo que se algumas pessoas "sustentam a espontaneidade como método" deve haver nela "um elemento primitivo de direção consciente", Gramsci considera importante distinguir aqueles que a compreendem "como método imanente e objetivo do devir histórico" daqueles "politiqueiros que a sustentam como método político". Pois, se nos "primeiros se trata de uma concepção equivocada; nos segundos se trata de uma contradição imediata e mesquinha que revela uma origem prática evidente, a saber, a vontade prática de substituir uma determinada direção por outra" ${ }^{22}$.

No entanto, Gramsci considerava fundamental a preservação da espontaneidade pois sendo estimulante e energética, ela seria "um elemento de unificação em profundidade", e sobretudo, um elemento fundamental para a negação da impressão de um movimento arbitrário, artificial e não historicamente necessário. Assim, admitindo a possibilidade de "unidade entre espontaneidade e direção consciente", o pensador indicava que a espontaneidade deveria ser "educada, orientada, depurada", por um "grupo já consciente" que deveria responsabilizar-se de converter movimentos espontâneos em "forças políticas positivas" ${ }^{23}$.

\footnotetext{
${ }^{21}$ Esta e todas as citações seguintes do pensador marxista são retiradas de "Espontaneidade e direção consciente". Escritos Políticos. 1931.

${ }^{22}$ Gramsci pensa aqui no aproveitamento de movimentos espontâneos para a aplicação de golpes. Ver mais adiante, nota 8.

${ }^{23}$ Este seria possivelmente o papel do intelectual em Gramsci. “...pode a teoria moderna encontrar-se em oposição com os sentimentos espontâneos das massas?” (...) “Não pode estar em oposição: entre uma e outras há diferença quantitativa, de grau, não de qualidade: tem que ser possível uma redução, por assim dizer, recíproca, um passo de umas à outra e vice-versa (Recordar que Kant queria que suas teorias filosóficas estivessem de acordo com o senso comum; a mesma posição se tem em Croce; recordar a afirmação de Marx na Sagrada Família, segundo a qual as fórmulas da política francesa da Revolução se reduzem aos princípios da filosofia clássica alemã). Descuidar - e mais ainda, depreciar - os movimentos chamados espontâneos, ou seja, renunciar a dar-Ihe uma direção consciente, a elevá-los a um plano superior inserindo-os na política, pode amiúde ter consequências sérias e graves. Ocorre quase sempre que um movimento espontâneo das classes subalternas
} 
Por outro lado, por parte daqueles que "sustentam a espontaneidade como método" costuma haver certa desconfiança em relação à existência de "grupos já conscientes". Além disso, a concepção de espontaneidade "como método imanente e objetivo do devir histórico", considerada simplesmente "equivocada" por Gramsci, repercute em níveis mais profundos, e não propriamente considerados pelo pensador. Antes dele, filósofos como Kant e Herder consideraram algo como um “'plano oculto' da natureza que, em detrimento dos fins conscientes dos indivíduos e do necessário conflito entre suas vontades, levar[ia] ao aperfeiçoamento de todas as disposições naturais da espécie humana" 24 (grifo meu). A história da humanidade teria assim, de acordo com estes pensadores, "algo de genial" e seria uma espécie de crença neste gênio imanente à natureza o que no limite demonstrariam os que sustentam a espontaneidade como método. O "elemento primitivo" da espontaneidade, tal como referido por Gramsci, ganha neste caso conotações bastante mais complexas uma vez que a noção de gênio sugere os vínculos profundos do homem com a natureza.

1.1 Notações filosóficas sobre a ideia de genialidade

O rechaço quase absoluto da noção de gênio do âmbito da arte moderna e contemporânea deve-se sobretudo à suspeita generalizada em relação ao caráter subjetivista, místico (e mítico) que costuma lhe ser atribuído. Não contribui certamente que o debate filosófico acerca do tema desde o idealismo alemão seja particularmente denso e intrincado, pois a mera ideia de retomada da questão torna-se então imensamente delicada ${ }^{25}$. De todo modo, a noção de gênio articula elementos como a inconsciência, a espontaneidade, a instintividade, a imediatez e a imprevisibilidade, traduzindo a ideia do artista "por excelência", ou ao menos a concepção de artista mais poética de que se tem notícia. Por mais problemático que isto nos possa parecer, esta é uma concepção que costuma ainda se fazer sentir, embora muitas vezes de modo não declarado,

coincide com um movimento reacionário da direita da classe dominante, e ambos por motivos concomitantes: por exemplo, uma crise econômica determina descontentamento nas classes subalternas e movimentos espontâneos de massas, por uma parte, e, por outra, determina complôs dos grupos reacionários, que se aproveitam da debilitação objetiva do governo, para intentar golpes de estado. Entre as causas eficientes destes golpes de estado há que se incluir a renúncia dos grupos responsáveis em dar uma direção consciente aos movimentos espontâneos para convertê-los assim num fator político positivo". Gramsci. "Espontaneidade e direção consciente". Escritos Políticos. 1931.

${ }^{24}$ Márcio Suzuki. O Gênio Romântico, p. 66-67.

${ }^{25}$ Meu tratamento do tema da genialidade não poderia ter ocorrido sem a referência fundamental ao livro $O$ Gênio Romântico - Crítica e história da filosofia em Friedrich Schlegel, de Márcio Suzuki. A este respeito, alerto meu leitor de que faço uma operação bastante incomum para os parâmetros acadêmicos, de apropriação e deslocamento de uma série de fragmentos do livro. Faço isso porque penso ser coerente com minha proposta de inserção da filosofia no campo da arte, e, claro, porque penso ser importante que algumas das questões desta pesquisa em particular sejam conhecidas e debatidas neste meio. 
revelando certo tipo de carência e nostalgia que não me parecem tão indevidos. A persistência daqueles sentidos tradicionalmente projetados na noção de genialidade, afinal, está relacionada à vocação transformadora, espiritual e transcendente da arte; vocação de que tanto se lamenta a perda em nossos dias, sem que, contudo, se reconsidere o suposto misticismo e subjetivismo implicados na noção de gênio. Na realidade, a ideia de gênio tem variadas facetas e no que se refere ao projeto político do romantismo, é particularmente notável o modo como seu desenvolvimento revela um aspecto "profético", ou "divinatório", a meu ver muito mais preciso do que aquele geralmente destacado em Hegel quando se recupera o tema do fim da arte.

É bem verdade que segundo algumas concepções a noção de genialidade tem algo de místico. De acordo com Márcio Suzuki, são desse tipo as ideias de Edward Young, autor das Conjecturas sobre a composição original, muito influente na Alemanha do Sturm und Drang. Edward Young propunha uma ideia orgânica de "gênio vegetal" segundo a qual a obra surgiria "espontaneamente da raiz vital do Gênio". "Como atividade espontânea”, em Edward Young, explica Márcio Suzuki, "a geração de uma obra original prescinde de um modelo a ser imitado, do saber técnico, do trabalho mecânico e até dos materiais prévios necessários para executá-la". Longe das regras, do estudo, e das convenções do gosto, o Gênio deveria "florescer naturalmente", em estado "puro", por suas próprias forças; o Gênio seria "o Deus em nós". ${ }^{26}$

A concepção de criação em analogia à ideia de "organismo" também aparece em Herder, para quem o "gênio está adormecido no homem, como a árvore no germe". Herder defende que não haveria projeção dos fins na atividade da natureza e, "suprimindo o intervalo entre o plano e sua realização", o gênio atingiria seu fim de modo imediato, instintivo e inconsciente. No entanto, isto seria apenas possível "segundo um modo de observação que não seciona os fenômenos e os isola do todo", o que se torna particularmente difícil quando o pensamento especializado e maquinal priva o indivíduo da perspectiva do todo. Por esta razão o gênio exigiria um cuidado especial em sua formação - cuidado necessário para despertar e fortalecer todas as inclinações e aptidões do homem, pois o gênio resultaria da melhor expressão de suas capacidades. ${ }^{27}$

Em Immanuel Kant, filósofo alemão responsável pela formulação mais fundamental para o desenvolvimento da estética durante a modernidade, a posição elevada do gênio fica evidente já pelo lugar que ocupa em sua terceira crítica, a Crítica da Faculdade de Julgar, sendo então tomado

\footnotetext{
${ }^{26}$ Márcio Suzuki complementa, acerca da visão de Young: "Como a vida secreta das plantas, a inspiração criadora é imperscrutável, tem algo de divino." Márcio Suzuki. O Gênio Romântico. p. 61- 60.

${ }^{27}$ Márcio Suzuki. O Gênio Romântico. p. 63.
} 
como meio de ligação entre a filosofia prática e a filosofia teórica, ou entre natureza e liberdade. Em sua consideração estética, Kant demonstra clara superioridade da natureza em relação à arte, pois a arte tenderia a atrair tipos "vaidosos, caprichosos e entregues a perniciosas paixões", enquanto os apreciadores da natureza revelariam "disposição de ânimo favorável ao sentimento moral" ${ }^{28}$. 0 único tipo de arte que interessava ao filósofo eram aquelas em que as regras seriam dadas pela própria natureza, o que poderia ocorrer apenas através do gênio, onde o espírito atuaria como "princípio vivificador da mente" e animaria a imaginação a produzir representações que seriam as Ideias estéticas.

O artista, segundo Kant, não pode indicar "como suas ideias surgem e se reúnem em sua cabeça", porque ele mesmo não o sabe, razão pela qual ele não pode ensinar seu ofício a ninguém ${ }^{29}$ - pode apenas incitar a reflexão, "despertar o gênio", pra que o aprendizado se desenvolva num eventual "discípulo" por conta própria ${ }^{30}$. Neste aspecto, Márcio Suzuki considera que a filosofia se aproxima da arte, pois embora o gênio filosófico deixe-se guiar pelo método da razão, ele também não possui clara consciência da Ideia e, como na arte, o espírito precisa possuir originalidade para "aproximar-se" dela através do livre desenvolvimento da reflexão. A Ideia racional, como a Ideia estética, se limita a pôr em atividade a reflexão que deve então desenvolver-se de modo independente, autônomo e livre de regras (sem prender-se à "letra"), até que se possa extrair uma unidade de apreensão (isto valeria tanto para o artista-criador, quanto para o "público-receptor"). 0 juízo reflexivo, para pôr de outro modo, aproxima-se da Ideia buscando esta "unidade inteligível capaz de abranger uma 'multidão de sensações e representações acessórias." ${ }^{31}$ Nesse sentido, o "prazer" do juízo estético, como destaca Virgínia Figueiredo, não seria nem imediatamente sensível, nem conceitual, mas propriamente reflexivo. ${ }^{32} \mathrm{O}$ trabalho do artista deve por "uma força sugestiva", como considera Kant, "dar muito o que pensar". É a ênfase no princípio da reflexão que permitirá à

\footnotetext{
28 "Kant: Liberdade da forma e forma da liberdade". Virginia Figueiredo. Em Os filósofos e a arte. Org. Rafael Haddock-Lobo. p. 60.

29 "todos os princípios descobertos por Newton podem ser explicados e demonstrados e, assim, apreendidos por quem quer que os estude, mas nenhum poeta (...) pode indicar como suas ideias 'surgem e se reúnem em sua cabeça, isto porque ele mesmo não o sabe e, portanto, também não pode ensinar a nenhum outro." Márcio Suzuki. O Gênio Romântico. p. 35-36.

${ }^{30}$ Márcio Suzuki. O Gênio Romântico, p.39

31 “....a intuição poética 'tem um 'parentesco muito próximo com a [intuição] filosófico-científica'”... "num caso como noutro, Geist ou imaginação produtiva se refere àquele talento que Kant define como capacidade de "exprimir o indizível de um estado-da-mente" e de "apreender o jogo rapidamente transitório da imaginação e unifica-lo em um conceito". Decisiva tanto na arte quanto na filosofia, essa capacidade, como lembra Rubens Rodrigues Torres Filho, está ligada à busca das condições transcendentais do conhecimento e à idéia de reflexão". Márcio Suzuki. O Gênio Romântico, p. 82.

32 Márcio Suzuki. O Gênio Romântico, p. 30-36.
} 
Kant recusar a ideia de que o gênio "vegetal" seria movido por uma espécie de "delírio inspirado", por uma "divindade interior", ou por uma "atividade instintiva". Assim, Kant advertia segundo Márcio Suzuki, que "para não escorregar pelo misticismo" seria preciso ter em conta que

quando se fala da natureza do gênio (aquela que dá regras à arte), se quer dizer o substrato supra-sensível, a natureza inteligível do homem. A natureza a que o gênio inconscientemente obedece não é uma força física ou vegetal: trata-se, ao contrário, da 'natureza no sujeito' e da 'disposição das faculdades do mesmo'(...) o 'dom natural', a 'disposição inata do ânimo pela qual a natureza dá à arte a regra', nada mais é que todo o conjunto das faculdades da mente, atuando, porém, sem ter ciência de como procede. Toda sugestão mística se dissipa quando se percebe que a atividade criadora age a partir de uma 'Ideia indeterminada do supra-sensível em nós'. O gênio não é outra coisa que a expressão mais acabada do modo de proceder do Juízo reflexionante, quando este compara a proporção entre as faculdades num determinado estado empírico da mente com a proporção ideal em que deveriam estar no desenvolvimento pleno, para ele inatingível, de todas elas. Como essa proporção não está previamente determinada por nenhum conceito, não existe imitação. Daí a necessidade do espírito, 'princípio vivificador da mente', 'Originalidade modelar do dom natural de um sujeito no uso livre de suas faculdades-deconhecimento'. (grifos meus)

A preservação do elemento da inconsciência do gênio em Kant, não o impede de reconhecer a importância da técnica e, ao contrário do que propunham concepções como as de Edward Young, a importância da "aparelhagem mecânica da arte", que seria para o espírito como o corpo "sem o qual evaporaria completamente." ${ }^{33}$ Ainda a respeito da proximidade entre arte e filosofia, Márcio Suzuki discute num outro texto - A palavra como invenção, Heurística e linguagem em Kant -, a contaminação do organismo pela técnica e da técnica pelo organismo, ambos contribuindo para a elucidação da Ideia. A partir de uma consideração do papel da imaginação no “esquematismo", Márcio Suzuki traça paralelos possíveis entre o âmbito linguístico e plástico através de noções como invenção, composição, execução, metáfora, e mesmo "perfeição estética" - todas referentes a este âmbito do espírito comum à arte e à filosofia no movimento reflexivo em direção à

\footnotetext{
33 “Apegando-se muito literalmente à concepção orgânica da criação, os defensores da genialidade perderam a verdadeira dimensão sistemática que comportava e é por isso que desprezaram tudo aquilo que fazia parte da aparelhagem mecânica das artes" (...) "não há nenhuma bela-arte na qual algo de mecânico não constitua condição essencial", "um mecanismo, sem o qual o espírito, que na arte tem de ser livre e é o único que vivifica a obra, não teria nenhum corpo e se evaporaria inteiramente" Márcio Suzuki. O Gênio Romântico, p. 69.
} 
Ideia. Mas a diferença entre arte e filosofia reaparece quando Kant considera que "a filosofia deve conservar o 'espírito de meticulosidade', e percorrer as 'trilhas espinhosas' da crítica", diferentemente da linguagem poética que seria justamente expressão simbólica dos "objetos em relação aos quais a filosofia é obrigada a se calar." ${ }^{34} \mathrm{O}$ caráter discursivo do conceito jamais alcança essa dimensão da linguagem que é apenas possibilitada pelo gênio: "não tendo nenhum conceito que Ihe possa ser adequado, a Ideia estética é a contrapartida de uma Ideia racional, que inversamente é um conceito ao qual nenhuma intuição (representação da imaginação) pode ser adequada'". A sugestão de certa complementaridade entre arte e filosofia em Kant é algo que não será ignorado pelos românticos.

Marcadamente influenciado por Kant, o filósofo também alemão Fichte, propositor da considerada "mais completa filosofia da genialidade" ${ }^{35}$, compreende que todo homem tem gênio, pois "todos os seres humanos têm espírito" e agem por uma espécie de "impulso do interior." Mas apenas os artistas, os homens genuinamente morais e os filósofos se elevam a ponto de fundar "o campo das Ideias e dos ideais". ${ }^{36}$ Como em Kant, esta elevação para o artista é inconsciente, ao passo que o gênio filosófico que seria "gênio para a verdade", agiria "para tornar claro ao espírito a própria espontaneidade a própria legislação, de que ele não tem consciência, mediante 'abstração e reflexão filosófica arbitrária'”. ${ }^{37}$ O movimento do filósofo de elevação é considerado em Fichte um movimento de "saída de si", ideia que será fundamental para os românticos:

O espírito humano não é capaz de intuir diretamente a própria atividade, pois para
poder apreendê-la tem, por uma lei que lhe é inerente, de fixa-la num objeto
exterior. Quando a imaginação 'imagina', não é consciente do imaginar, mas
unicamente da imagem. A consciência comum não age e, ao mesmo tempo,
observa como age. Esta é uma habilidade própria do filósofo ou, mais exatamente,
do 'gênio filosófico', isto é, o talento de encontrar, no e durante o próprio agir, não
apenas aquilo que nele surge, mas também o agir como tal, de unificar, numa
apreensão, essas duas direções totalmente opostas e, assim, captar o seu próprio
espírito em ação'. Na consciência comum, a intuição do próprio agir se eleva à

\footnotetext{
${ }^{34}$ Márcio Suzuki. O Gênio Romântico. p.57

${ }^{35}$ Rubens Rodrigues Torres Filhos, citado por Márcio Suzuki, em O Gênio Romântico, p. 16

${ }^{36}$ Márcio Suzuki. O Gênio Romântico, p. 83.

${ }^{37}$ Márcio Suzuki. O Gênio Romântico, p. 84. Num sentido semelhante, Schelling, na esteira de Fichte considera que o filósofo eleva, a si e a outros, "com trabalho e conforme uma regra", enquanto o artista, o "belo espírito", eleva o homem em sua totalidade, porém, "sem pensar nisso determinadamente": "ele eleva tão imperceptivelmente os que se abandonam à sua influência, que estes não têm consciência da passagem. Márcio Suzuki, em O Gênio Romântico, p. 102.
} 
clareza do pensamento, mas ao mesmo tempo nele se perde como atividade, pois sua ação é fixada na forma de conceito. Todo o empenho da filosofia transcendental é mostrar como se dá essa estabilização da atividade inconsciente do eu no seu objeto. Mas para conseguir fazer isso ela tem de poder apreender, como atividade, a própria agilidade: ter consciência da intuição', diz Fichte, 'é gênio filosófico' ${ }^{38}$

Dada a distância entre o ponto de vista transcendental do filósofo e o ponto de vista do homem comum, a diferença principal entre o modo de proceder do artista e do filósofo, segundo Fichte, é que enquanto este eleva ao ponto de vista transcendental apenas um fragmento do homem ("apenas o entendimento ou, como o moralista popular, apenas o coração") "com trabalho e conforme uma regra", exigindo "um enorme esforço de abstração e distanciamento de si", o artista eleva "imperceptivelmente" o homem inteiro, "sem nenhuma regra ou preceito metódico", descobrindo "pelo instinto", "quase sem se dar conta, uma feliz proporção entre a limitação da atividade real (o mundo é percebido como dado) e a liberdade da atividade ideal (o mundo é produzido)" ${ }^{39}$. Assim, a estética é reconhecida entre o ponto de vista transcendental e o comum, no centro, como mediadora, ${ }^{40}$ e o artista como aquele que "torna o ponto de vista transcendental ponto de vista comum" ${ }^{41}$.

A exigência fichtiana de "ao mesmo tempo pensar, agir e observar" torna-se para os românticos o ideal de todo filosofar. ${ }^{42}$ Mas se para Fichte, o filósofo "deve se limitar a observar e descrever rigorosamente o que vê", e o homem comum, "este sim, vive e produz o conhecimento

\footnotetext{
${ }^{38}$ Márcio Suzuki. O Gênio Romântico, p. 87.

39 Isso pode ser considerado de modo bastante simples no processo de trabalho de um pintor, quando sua atuação no plano estético torna-se efetiva ao manipular o corpo no plano físico, como num gesto que se converte em pincelada: aquilo que Ihe parece dado é o que ele mesmo produz, e o que ele produz é o que lhe parece dado. Por isso diz-se que o gênio estético seja natural, e o gênio filosófico, artificial - este último abstrai "descolado" do plano estético, enquanto o primeiro abstrai junto a ele, "integrado".

40 "Está faticamente provado que existe um tal mediador entre o ponto de vista transcendental e o comum: esse centro é a estética. No ponto de vista comum o mundo aparece como dado; no ponto de vista transcendental, como feito (tudo em mim); no ponto de vista estético, aparece como dado, de tal modo como se nós o tivéssemos feito e como nós mesmos o faríamos". Aqui o condicional "como se" deve-se ao fato de que o filósofo tem em vista o "receptor", aquele que percebe o que é dado no plano estético como já feito, como quando se depara com uma obra pronta. Márcio Suzuki. O Gênio Romântico. p. 101

${ }^{41}$ Márcio Suzuki. O Gênio Romântico, p. 87.

${ }^{42}$ Como considera Novalis: "Podem nascer aqui prodigiosas obras de arte - se um dia se começar a praticar artisticamente o fichtizar." Citado em M. Suzuki. O Gênio Romântico, p. 97.
} 
real" ${ }^{43}$, os românticos assumem como projeto a tarefa de "elevar-se ao ponto de vista transcendental e torná-lo ao mesmo tempo ponto de vista comum", operando assim uma aproximação da arte e devolvendo a filosofia de volta à vida ("à dimensão original da consciência"), de modo que ela possa "se desfazer de seu aparato técnico e readquirir as cores de uma apresentação realmente 'viva'”:

para 'escapar do solipsismo teórico que isola a subjetividade e separa para sempre representação e objeto, é necessário - paradoxalmente - mergulhar cada vez mais fundo no espírito e perceber que o eu é capaz de um 'casamento feliz consigo mesmo' ('ato de auto-amplexo') e de 'fazer companhia a si mesmo'. ${ }^{44}$

A filosofia assim deve afirmar e explorar "toda a densidade da vida", deixando "de ser uma pálida visão esquemática, um produto artificial, para se tornar saber efetivo, uma obra de arte" ${ }^{45} \mathrm{~A}$ "vida" afirmada pelo romantismo, naturalmente, é a vida particular, do indivíduo, pois para os românticos, como explica Novalis, "não existe unificação possível entre filósofo e homem senão por intermédio do gênio individual de cada um, pois o sistema, (...) jamais escapará da esfera da filosofia individual..." 46 "Eis aí o que se poderia chamar o 'programa' do romantismo: a artificialidade da construção filosófica deve ser 'devolvida' à vida, transformando-se em obra de arte. O homem tem de ser ao mesmo tempo filosofia e vida, "vida ideal" e 'filosofia real' - 'vivente teoria da vida'”. ${ }^{47}$

\footnotetext{
${ }^{43}$ Para Fichte, o ponto de vista transcendental e o ponto de vista do homem comum podem apenas conviver no filósofo, mas sem qualquer possibilidade de entendimento pois: "Viver é bem propriamente não-filosofar; filosofar é bem propriamente não-viver". O Gênio Romântico. M. Suzuki, p.100

${ }^{44}$ Márcio Suzuki. O Gênio Romântico. p. 90.

${ }^{45}$ Márcio Suzuki. O Gênio Romântico. p. 96

${ }^{46}$ Numa passagem citada por Márcio Suzuki, Schlegel escreve: "A razão é apenas uma e, em todos, a mesma; como entretanto cada homem tem sua própria natureza e seu próprio amor, também traz em si sua própria poesia. Que precisa e deve ser preservada, tão certo quanto é aquele que é, tão certo quanto nele houve alguma coisa de original; e nenhuma crítica pode ou deve lhe roubar a essência mais própria, a força mais íntima, para o decantar ou purificar numa imagem genérica sem espírito e sem sentido [...] Mas a elevada ciência da crítica genuína lhe deve ensinar como tem de formar a si mesmo em si mesmo e, antes de tudo, deve lhe ensinar a aprender também toda outra figura autônoma da poesia em sua clássica força e plenitude, para que as flores e o germe de espíritos alheios se tornem alimento e semente de sua própria fantasia". Márcio Suzuki. O Gênio Romântico. P. 119.

${ }^{47}$ Em outro ponto, Márcio Suzuki considera: "Não se trata, portanto, somente de descobrir e revelar a filosofia natural contida no gênio, criador inconsciente de um mundo ao mesmo tempo ideal e real; num sentido inverso, é necessário tornar metódica a genialidade filosófica artificial, para que a unificação entre os pontos de vista possa ser empreendida como produção de uma obra de arte" Márcio Suzuki. O Gênio Romântico. p. 97.
} 
a 'reflexão necessária do eu sobre si mesmo é o fundamento de todo sair de si mesmo'. Refletir sobre si, ensina a doutrina-da-ciência, implica sair de si, pôr um outro, um não-eu; querer manter-se no interior da especulação filosófica, replica o romantismo, é como velejar indefinidamente em mar alto, sem ter como voltar ao porto de onde se partiu. A filosofia deve deixar a imanência da razão, fazer-se de novo transcendente, sair de si, para voltar a ser novamente 'filosofia da vida', isto é, tornar-se o 'produto da filosofia de um filósofo e de sua vida' ${ }^{48}$.

O movimento proposto pelos pensadores românticos, porém, não se restringe à filosofia, pois a mesma espécie de "insuficiência intrínseca" à filosofia que a leva a se aproximar da arte em seu "retorno à vida", é admitida também do lado da arte, "como se o poeta precisasse da clareza de espírito do filósofo". Esta "propensão inconsciente e irresistível" se explica pelo fato de a época moderna ser, como considera Kant, "a época da crítica”: “A disposição de se submeter a exame e, com isso, buscar a formação das próprias faculdades pressupõe como momento complementar a capacidade de compreender um outro, que irá tirar do adormecimento potencialidades até então insuspeitadas pelo próprio indivíduo". Assim, sendo o outro da filosofia, a arte, e o outro da arte, a filosofia, o que se busca é "mediação e iluminação recíproca". Para ser um "'gênio completo'”, o filósofo e o poeta terão de se tornar um crítico histórico', o único capaz de entender os dois".

\begin{abstract}
A filosofia deve sair de si e encontrar a poesia (doutrina-da-ciência); a poesia, sair de si e encontrar a filosofia (doutrina-da-arte). Ambas se unificam na política superior. É assim que se apresenta o projeto 'político' do romantismo. Tal projeto também pode se apoiar na constatação histórica segundo a qual 'toda a história da poesia moderna' é no fundo um comentário ao 'breve texto da filosofia' que diz: 'toda arte deve se tornar ciência e toda ciência, arte; poesia e filosofia devem ser unificadas' 49
\end{abstract}

\title{
1.2 Transição
}

Certamente os românticos não tinham, como ninguém poderia ter, qualquer noção do modo como as artes se desenvolveriam a partir daquele período. O aspecto "divinatório" do

\footnotetext{
${ }^{48}$ Márcio Suzuki. O Gênio Romântico. p. 121-122

${ }^{49}$ Schlegel, citado em Márcio Suzuki. O Gênio Romântico. p. 187.
} 
pensamento romântico a respeito da arte, contudo, pode ser considerado no movimento de "conscientização" e aproximação da filosofia de que este trabalho é certamente um exemplo. Com efeito, é já uma dimensão crítica que começa a aparecer no realismo, por exemplo, assim como nas exposições independentes como a de Courbet, realizada em 1855, e o conhecido Salão dos recusados, de 1863, - ambas marcos do início das vanguardas para uma série de pensadores. Para além da dimensão crítica da série de movimentos vanguardistas (que fez das artes visuais, dentre todas as práticas artísticas da tradição moderna, aquelas que romperam mais radicalmente com as limitações formais de seu campo tradicional), há também um conhecido aspecto crítico no movimento de autorreflexão que define a teoria formalista mais conhecida, proposta por Clement Greenberg. Como previsto, enfim, a arte se tornou "crítica-histórica" e se transformou. Na medida em que a derrubada da noção de genialidade estética indica o deslocamento crescente de noções como espontaneidade, instintividade, imediatez e inconsciência, é ao longo deste processo que perdem-se justamente os traços mais específicos e distintivos da arte em relação à ciência, no caso, a filosofia. Posto dessa forma, de que modo o fim da arte tal como proposto em Hegel não seria uma "profecia" mais acertada do que a romântica?

Ora, muito antes do romantismo e de Kant, já se reconhecia no artista um ser criador com certa "inclinação natural" e qualidade divina. ${ }^{50}$ Se considerarmos a dimensão ritualística dos primórdios da arte, este vínculo era ainda mais profundo. Como escreve Peter Bürger, não é exatamente como se a arte estivesse meramente vinculada à rituais, pois na realidade ela os constituía; era parte dos rituais, e não uma prática que se poderia pensar à parte deles ${ }^{51}$. Nesse sentido, o que a própria fundação da estética representa com suas subsequentes acepções de genialidade, é o momento em que a dimensão espiritual da arte se torna consciente pelo próprio exercício reflexivo do pensamento - aquele conhecido processo moderno de racionalização da existência estendido à qualidade divina até então inerente à arte. Este é justamente o fenômeno que anuncia o tema do fim da arte em Hegel. ${ }^{52}$

Mas ao passo em que o movimento da filosofia que torna a arte consciente é compreendido pelos românticos como um momento de fusão, em que de um lado a filosofia teria o que aprender

\footnotetext{
${ }^{50}$ Isso pode ser verificado por exemplo no tratamento quase religioso que Leon Alberti confere à arte em seu tratado Da Pintura.

51 “A arte completamente ligada ao ritual não pode ter estado alinhada porque não pode dar-se como um âmbito especial. A obra de arte é aqui parte do ritual. Só uma arte que tenha atingido uma relativa autonomia pode tomar posição. Assim, pois, a autonomia da arte é também a condição de uma heteronomia posterior." (Peter Bürger, 1993, nota 8, pg. 98)

52 Hegel compreende o ultrapassamento do "estágio no qual se podia venerar e adorar obras de arte como divinas", considerando que o "pensamento e a reflexão sobrepujaram a bela arte." G. W. F. Hegel. Cursos de Estética, p. 34-35.
} 
com a arte num processo de adensamento e retorno à vida, e de outro, a arte teria o que a aprender com a filosofia, num processo de saída de si e conscientização do próprio gênio, Hegel, inversamente, preserva o estado de pureza da filosofia em sua posição idealista e a partir da compreensão de um "mundo reflexivo", compreende no processo de conscientização da arte, um movimento unilateral desta em direção à filosofia, área em que então a arte se dissolveria sem chances de escape. Enquanto os românticos não cansam de considerar a compatibilidade da arte com a filosofia, aproximando-a da poesia e considerando a relevância dos aspectos formais e estilísticos do texto filosófico, ${ }^{53}$ Hegel compreende que a consideração "apenas" pensante da filosofia "abstrai da massa de particularidades" e destrói a efetividade da arte com "a árida secura sem luz do conceito".

Que o caráter profético dos escritos de Hegel em relação à arte seja destacado desde a década de 60 do último século com muito mais ênfase que aquele dos pensadores românticos, me parece ajustado ao fato de que alguns dos termos mais amplamente difundidos a respeito da arte em nossos tempos sejam "decadência”, "crise”, "nostalgia", "luto”... É verdade que em parte são estes traços que suscitam a referência à Hegel e ao tema do fim da arte, mas por outro lado, "a negatividade absoluta" do pensamento hegeliano, puramente lógico ${ }^{54}$, reatualiza as condições do diagnóstico a cada vez que é feito, pois o que quer que se proponha no campo da prática ou da teoria possui uma dimensão afetiva e retroalimenta todo o processo. A confirmação sucessiva deste estado sugere uma espécie de regozijo niilista com a ruína assistida das bases sobre a qual toda a tradição moderna da arte se erigiu. Para usar os termos propostos por Yve-Alain Bois a partir de Hubert Damisch em A Pintura como Modelo, é preciso ter claro a distinção entre jogo e partida para não confundir o que deveria constituir o fim de narrativas específicas com conclusões mais dramáticas e definitivas. ${ }^{55} \mathrm{O}$ aspecto espiritual da arte não é um fenômeno moderno como é a

\footnotetext{
${ }^{53}$ Considerando a partir de Novalis e Schlegel que a reflexão filosófica transcendental não pode ser descolada de sua 'exterioridade', Suzuki escreve: "Se este é o caso a filosofia também tem de ser estudada sob os aspectos de sua forma retórica ou poética, pois a partir do momento em que já não se lida com uma pretensa linguagem lógica neutra, depurada, mas com a fala densa e viva dos indivíduos, já se está no âmbito de uma análise do estilo. Mas tal análise estilística depende de uma mudança considerável no estatuto da crítica, investida agora da tarefa de examinar a conformação orgânica original que assume em cada autor a síntese de universalidade e particularidade, real e ideal, filosofia e vida. Uma vez que o conceito de estilo não se limita à filologia, mas também se aplica aos textos filosóficos, a crítica da filosofia será de todo impensável sem crítica literária". Márcio Suzuki. O Gênio Romântico, p. 118.

54 “o princípio da razão dialética que molesta e destrói a vida é exatamente aquilo que antes de mais nada tem de ser evitado e vencido'. Seguir a natureza dialética do espírito, como quer [...] Hegel, significa entronizar um princípio negativo, a superação abstrata de uma oposição engendrada exclusivamente pelo pensamento, e ao mesmo tempo destruir a positividade, a harmonia real de todas as disposições da alma". Márcio Suzuki. O Gênio Romântico, p. 151-152

${ }^{55}$ Yve-Alain Bois recorre à teoria dos jogos para sugerir a pintura como um jogo e a pintura moderna como partida, ou partidas, realizada(s) durante a modernidade. Assim, considera: “...a ficção do fim da arte (ou da pintura) é percebida como uma confusão entre o fim do próprio jogo (como se um jogo pudesse, de fato, ter fim)
} 
pintura de cavalete; e se nem mesmo no núcleo do pensamento romântico a tendência à filosofia pôde ser ignorada, então ao invés de compreendê-la no sentido hegeliano, certamente excessivamente "árido" para quem ainda reconhece na dimensão sensível sentidos que não se deixam subsumir a conceitos, podemos alternativamente nos orientar em direção àquela nova acepção de filosofia proposta pelo romantismo a partir de Fichte, segundo a qual "a filosofia não pode 'existir separadamente sem aquilo que lhe é 'diametralmente oposto', sem o seu pólo positivo, que 'já não pode ser filosofia'” ${ }^{56}$. O romantismo, neste aspecto, certamente não está sozinho, pois se os próprios românticos descobriram na mitologia grega a origem comum da arte e da filosofia ${ }^{57}$, e tomaram particularmente os pré-socráticos como fonte de inspiração, a mesma fonte serviu também para fazer falar Zaratustra, por exemplo. Pensadores como Nietzsche, Bergson, MerleauPonty, Foucault, Deleuze, são claros exemplos de filósofos abertos à "contaminação" pelo sensível; se isto ocorre porque ela toma a vida como objeto, então me parece perfeitamente plausível que a contaminação seja recíproca como queriam os românticos. É claro que em certo sentido, como já considerou Karl Jaspers, "toda filosofia é filosofia da vida", mas se tomarmos como base, por exemplo, o marxismo, por sua própria linhagem hegeliana, faremos bem em reconecta-lo à um plano espiritual e romântico, possibilidade apontada por pensadores como Michel Foucault e Jacques Rancière. ${ }^{58} \mathrm{~A}$ meu ver, conexões deste tipo sempre nos trarão de volta da filosofia à vida, pra que então um jogo estético - reflexivo e dialético - possa ser experimentado num âmbito mais amplo, que permita inclusive considerar a ciência, não apenas as humanas, mas também as naturais, tais como física, química, biologia, e enfim, "todas as coisas". Pois se Schiller - autor das Cartas sobre a educação estética do homem e importante referência ao românticos -, destacava o potencial

e o fim desta ou daquela partida (ou série de partidas)". "A Pintura como Modelo", em Yve-Alain Bois. A pintura como modelo, p.291-292

${ }^{56}$ De acordo com Márcio Suzuki, Schlegel indica "uma outra leitura da 'evolução' do idealimo, pensado agora não mais como desenvolvimento especulativo que vai de Kant a Hegel, mas, exatamente ao contrário, como indagação e problematização progressiva do poder da especulação. Essa radicalização dos princípios críticos acaba culminando na chamada crise da filosofia". Márcio Suzuki. O Gênio Romântico, p. 153.

57 Sobre a origem comum entre arte e filosofia, Márcio Suzuki cita Schlegel: "o 'pressentimento do incondicionado', é sempre um 'primeiro passo para um mundo inteiramente outro', 'o começo de uma nova etapa da formação'. As danças em volta da imagem de Ártemis, o sacerdote que a converte em natureza, o artista que a figura alegoricamente, o poeta que a canta em seus versos, e Heráclito, que deposita seus escritos no templo da deusa: 'todos eles, por mais diferentes que fossem a forma de comunicação e a clareza de seus conceitos, estavam entusiasmados por um único e mesmo objeto. Estavam tomados pela viva representação de uma infinitude incompreensível. Ora, se essa representação é começo e fim de toda filosofia, e se esse primeiro pressentimento dela se exterioriza nas danças e cantos báquicos, nas festas e ritos entusiásticos, nas imagens e poemas alegóricos, então as orgias e mistérios são os primórdios da filosofia grega; e não foi uma idéia feliz começar a sua história com tales, fazendo-a surgir subitamente do nada. Não deveríamos, portanto, considerar as orgias e mistérios gregos como nódoas estranhas e desvios causais, mas considera-los, com veneração como um componente essencial da formação antiga, como uma etapa necessária do desenvolvimento gradual do espírito helênico" Márcio Suzuki. O Gênio Romântico, p. 228-229

${ }^{58}$ Michel Foucault. A Hermenêutica do Sujeito, p.28. Jacques Rancière. A Partilha do Sensível, p.67. 
"totalizante" da experiência estética, então talvez seja legítimo num mundo tão fragmentado arriscar movimentos contrários ao dilaceramento da modernidade. Como uma das poucas áreas em que o "afã totalizador" do homem pode ser perdoado, penso que a arte seja um campo privilegiado para a organização destes movimentos. Naturalmente, neste processo, é ainda a controversa e problemática autonomia da arte que deve ser explorada. ${ }^{59}$

${ }^{59}$ Ver nota sobre autonomia da arte, p. 63. 


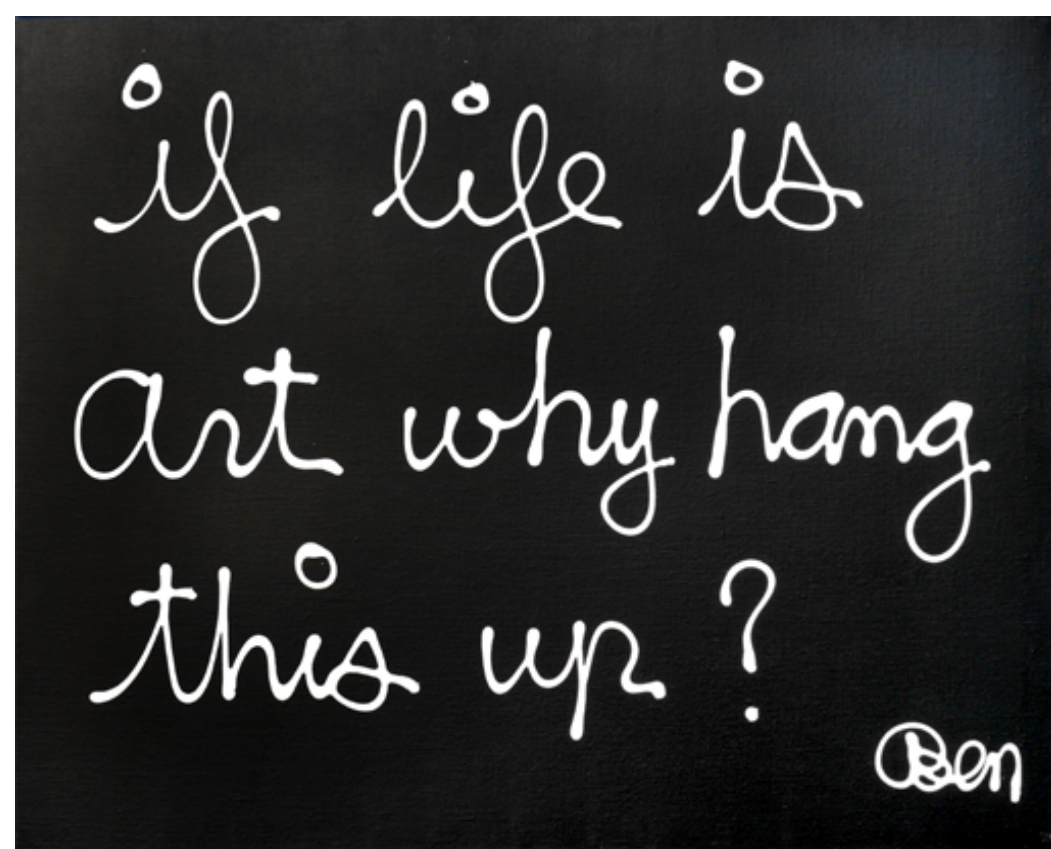

Ben Vautier, s/d. 


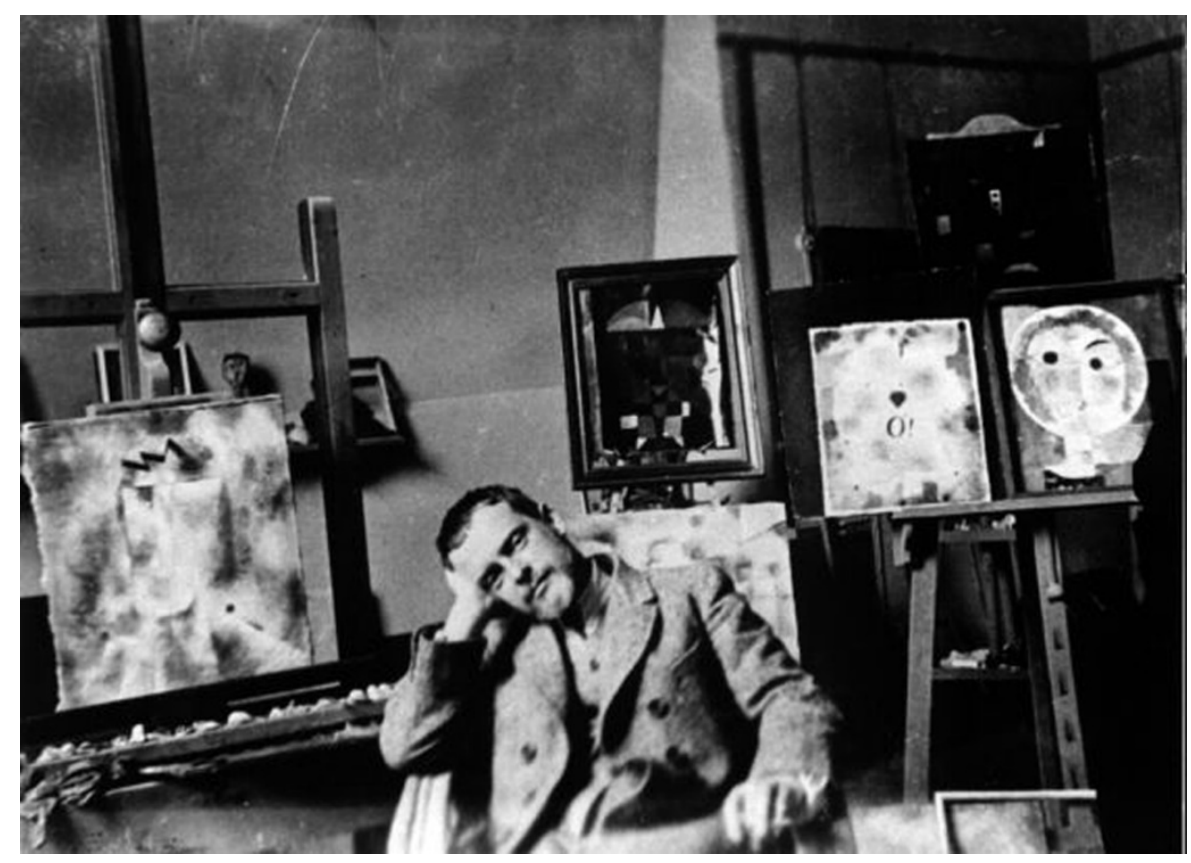

Paul Klee

"Fico possuído pela cor; não preciso de ir à procura dela. Ela possui-me para sempre, sei-o. Eis o sentido do momento feliz: a cor e eu somos um. Eu sou pintor".

Paul Klee 


\title{
Parte 2
}

\section{Em direção à vida como arte - a filosofia realizada}

\author{
O exemplo da pintura como modo de vida e a transformação como termo conciliatório entre \\ crítica e espiritualidade
}

Para a maior parte dos pensadores do idealismo alemão, a arte enquanto experiência se caracterizaria pela suspensão de oposições, tais como entre pensamento e sensibilidade, sujeito e objeto, ou liberdade e natureza. O sentimento de completude daí resultante, como sugere Klee, atualizaria a ideia de unidade que na filosofia geralmente se projeta na antiguidade. A arte seria, e esta era a aposta de Schiller com seu projeto de educação estética, uma força contrária à fragmentação e às grandes cisões da modernidade. Junto ao aspecto "totalizante" da experiência estética, o filósofo relacionava, naturalmente, sua dimensão espiritual. Segue-se daí, particularmente com o romantismo, que o lugar possível da transcendência não seria um além qualquer, mas propriamente o plano estético, compreendido como o momento necessariamente presente em que a sensibilidade se desdobra pela percepção; não do lado "de fora", como algo que se assiste, mas como algo com que se está integrado pelo próprio corpo, numa "relação carnal com o mundo", como queria Merleau-Ponty.

A distinção entre experiências estéticas e experiências comuns que eventualmente possam ser obtidas por meio de quaisquer outras práticas, pode ser considerada a partir da distinção entre pintura e ilustração proposta inúmeras vezes por Francis Bacon ao longo de uma série de entrevistas com David Sylvester: "até hoje", considera o artista, "nunca se analisou (...) o porquê dessa maneira de pintar ser mais profunda do que a ilustração" 60 . A "maneira" a que o artista se referia era "muito, muito solta", "sem saber o que estava fazendo." Bacon é um desses artistas que no quadro sugerido no início desta pesquisa, ficaria certamente no primeiro grupo. Nesta mesma entrevista ele fala de imprevisibilidade, inconsciência, irracionalismo, acaso, de acidentes, de espontaneidade, da vitalidade do imprevisto, de evitar a lógica, de ver-se livre de fórmulas, etc. $\mathrm{O}$ artista considera a distinção entre a pintura e a ilustração um "problema muito difícil de ser expresso em palavras", tem a ver com "instinto": "a pintura toca diretamente no sistema nervoso e a ilustração conta uma história num longo discurso através do cérebro".

${ }^{60}$ David Sylvester. Entrevistas com Francis Bacon, p. 17. 
FB - Veja bem, nós temos uma intenção, mas o que realmente acontece é produzido durante o trabalho, essa é a razão por que é tão difícil falar sobre isso. Realmente, é no trabalho que acontece. E a maneira como isso funciona depende realmente das coisas que acontecem. Enquanto trabalhamos, vamos seguindo qualquer coisa parecida com uma nuvem, que é feita de sensações e está dentro de nós, mas não sabemos realmente o que ela é. $E$ isso é chamado de instinto. $E$ o instinto da pessoa - não interessa se certo ou errado - se fixa sobre certas coisas que acontecem no ato de pôr a tinta sobre a tela. Acho que boa parte da criação também é constituída pela autocrítica do artista, e muitas vezes acho que, provavelmente, o que faz um artista parecer melhor do que outro é um senso crítico mais apurado. Pode ser que não seja nem um pouco mais talentoso, mas o seu senso crítico é simplesmente melhor.

DS - E no uso de seu senso crítico, ele não tem critérios definidos. É um tipo de senso crítico puramente instintivo. É isso que você quer dizer?

FB- É isso. Sim, é isso ${ }^{61}$.

Kant, Fichte e os românticos já consideravam o aspecto "indizível" da arte - algo que também aparece em Klee e inúmeros outros artistas. A instintividade é também um aspecto que aparece, por exemplo, em Herder, discípulo de Kant, como vimos. De fato, o filósofo "veta" a possibilidade ao artista de projetar fins, de modo que ele tomaria o meio como fim, algo muito próximo do que seu mestre propunha com a noção de "finalidade sem fim." Uma narrativa é justamente uma "projeção", e representa a perda da qualidade imediata do trabalho instintivo então considerado importante. O ponto, enfim, é o reconhecimento da relação destas características àquela qualidade "profunda" a que se referia Bacon, ou "totalizante", como sugeria Klee.

Se considerarmos, num âmbito bastante diverso, a dimensão espiritual da psicanálise ou do marxismo, como Foucault indicava ser possível, certamente também aí estes termos estão presentes. É claro que são práticas bastante distintas, mas elas tendem cada qual a seu modo àquele momento visado de completude e totalização (que define a própria ideia de espiritualidade) e, curiosamente, muitas vezes, coincidem em termos, como "espontaneidade" - muito naturalmente, na realidade, pois a ideia de espontaneidade é contrária à de especulação, ou de dissociação do pensamento e assim tenderia ela mesma à ideia de completude ou integridade. É o caso sugerido por aquela "unidade" desejada por Gramsci entre espontaneidade - "elemento de unificação em profundidade" -, e direção consciente. No limite, o desejo do teórico marxista não é tão diferente da

\footnotetext{
${ }^{61}$ Entrevistas com Francis Bacon, p. 149.
} 
vontade romântica de unidade entre arte e filosofia ${ }^{62}$ - um retorno à espontaneidade do gênio natural depois do movimento de dissociação do gênio artificial, ou um gênio natural que seja consciente. Em todo caso, o fim de toda prática espiritual é a experiência que ela promete, experiência que, como depende de uma operação no mundo sensível, é estética. Até que se chegue a ela, no entanto, o que se encontra é processo; é trabalho, como dizia Francis Bacon. Compreendidas as coisas deste modo, o "mundo da arte" está, decerto, demasiado apegado aos limites dados por uma tradição específica quando sem perspectivas lamenta a "banalização" ou a "decadência" do estado atual de coisas, sem perceber os desdobramentos da arte em âmbitos mais amplos. É precisamente o que Jacques Rancière sugere quando considera que a estética tornou-se "o lugar privilegiado em que a tradição do pensamento crítico se metamorfoseou em pensamento do luto", e quando de modo muito pouco usual considera "vãos" os debates acerca da autonomia da arte, propondo pensar a arte enquanto trabalho ao invés de em oposição ao trabalho ${ }^{63}$.

Com efeito, a oposição entre arte e trabalho, naturaliza uma distintividade de muito pouco interesse se desejamos recusar a questão do distanciamento entre arte e vida. Naturalmente, a vida de que a arte se afasta com a valorização da dimensão estética é apenas aquela que se deixa definir pelas "atividades interessadas do espírito". Mais propriamente, estas atividades é que afastam o sujeito de sua própria vida, tal como é o caso do trabalho alienado, como define Marx em seus Manuscritos econômico-filosóficos:

\begin{abstract}
Em que consiste, então, a alienação do trabalho? Primeiro, no facto de que o trabalho é exterior ao trabalhador, isto é, não pertence à sua natureza, que não se realiza no seu trabalho, que se nega nele, que não se sente à vontade, antes se sente infeliz, que não desenvolve nenhuma energia física ou mental que seja livre, mas antes que se mortifica e arruína o seu espírito. O trabalhador, assim, só é ele próprio quando não trabalha, e no seu trabalho sente-se fora de si próprio. 0 seu trabalho, por isso, não é voluntário, mas forçado. Não é a satisfação de uma necessidade, mas somente uma forma de gratificar a necessidade de outrem.
\end{abstract}

O tema da arte em oposição ao trabalho aparece afirmado, por exemplo, no livro de entrevistas de Marcel Duchamp à Pierre Cabanne. $\mathrm{O}$ artista, porém, recusa-se a tomar a arte como

\footnotetext{
${ }^{62}$ Para considerações mais detalhadas sobre as bases românticas de Marx, e sobre possíveis aproximações entre romantismo e marxismo, ver Romantismo e Política, de Michael Löwy e Robert Sayre, ou ainda Romantismo e Messianismo, de Michael Löwy.

63 Jacques Rancière. A Partilha do Sensivel, p. 66-69.
} 
trabalho denunciando, neste âmbito, limitações relacionadas à condutas programadas e ao medo de inovação. Nesse sentido, Marcel Duchamp demonstra compreender o trabalho num sentido muito aproximado do denunciado por Marx. Jacques Rancière, porém, com sua recusa em considerar a arte em oposição ao trabalho faz uso estratégico do caráter distintivo da arte para desnaturalizar a ideia segundo a qual o trabalho é necessariamente limitante e negativo. Notavelmente, uma concepção de trabalho muito diversa, segundo Rancière, fortemente influenciada pelo pensamento do idealismo alemão acerca da arte, pode ser identificada no próprio Marx, naqueles mesmos Manuscritos:

\begin{abstract}
Suponhamos que produzimos como seres humanos. Cada um de nós ter-se-ia afirmado de duas formas: (1) na minha produção teria objetivado a minha individualidade, o seu carácter específico, e portanto apreciado não somente a manifestação individual da minha vida na atividade, mas também ao contemplar o objeto teria o prazer individual de reconhecer que a minha personalidade é objetiva, visível para os sentidos e portanto um poder acima de dúvida, (2) no uso do meu produto teria um prazer direto pelo facto de estar consciente de ter satisfeito uma necessidade humana com o meu trabalho, ou seja, de ter objetivado a natureza essencial do ser humano (...). Os nossos produtos seriam outros tantos espelhos em que se refletiria a nossa natureza essencial.
\end{abstract}

De acordo com Rancière, o procedimento artístico contraria "uma ideia da sociedade fundada sobre a oposição entre os que pensam e decidem e os que são destinados aos trabalhos materiais". Assim, o filósofo recupera a dimensão "totalizante" da experiência artística propondo que a produção em arte

une num mesmo conceito os termos tradicionalmente opostos da atividade fabricante e da visibilidade. Fabricar queria dizer habitar o espaço-tempo privado e obscuro do trabalho alimentício. Produzir une ao ato de fabricar o de tornar visível, define uma nova relação entre o fazer e o ver.

A relação imediata entre o ver e o fazer, relacionada a suspensão de oposições de que falava Schiller em sua Educação Estética, permite que a atividade fabricante torne-se visível, o que se relaciona diretamente ao reconhecimento e à valorização da dimensão processual do trabalho de arte. Para Nicolas Bourriaud, esta seria a "principal virtude da arte moderna", pois representaria a 
negação em "considerar o produto acabado e a vida a ser vivida como sendo separados." Para o artista, considera Bourriaud, "criar é criar a si mesmo." ${ }^{64}$

“Faz-se pintura porque se quer a tão falada liberdade. Mas ninguém quer ir ao escritório todas as manhãs".

Marcel Duchamp

Bourriaud explora, em seu livro notavelmente intitulado Formas de Vida: a arte moderna e a invenção de si, a relação entre arte e vida a partir da consideração de uma série de trabalhos cujas formas sugerem, de modo direto ou indireto, os gestos, comportamentos, atitudes e "estilos de vida" muito particulares que propiciaram suas produções ${ }^{65}$. O pensador considera que na arte "obra e existência se imbricam em processos de produção de 'possibilidades de vida individuais'". Destacando "certa atitude filosófica" e/ou "transgressiva", Bourriaud lembra, por exemplo, da polêmica visita de um pintor a uma prostituta no século XIX, em Olympia, de Manet; da saída à campo de pintores impressionistas, como Monet; do "turismo pictórico" em Gauguin; das "noitadas" dadaístas; do judô em Yves Klein; do xamanismo em Joseph Beuys; e mesmo do dinamismo imersivo da pintura de Jackson Pollock. O reconhecimento do valor da obra de arte moderna, insiste Bourriaud, está indissociavelmente relacionado ao reconhecimento do valor dos gestos, dos comportamentos e da mentalidades "por trás" das obras. Por esta indissociação histórico-subjetiva que se desdobra a partir daquela "virtude" destacada por Bourriaud, a obra de arte moderna nega, por ela mesma, aquela propagandeada oposição ao distanciamento entre arte e vida durante a época moderna. Pois a despeito da qualidade "intemporal" da experiência estética, o modo como ela se afirma é sempre histórico, pois está intrinsecamente relacionada às condições sensíveis da

\footnotetext{
${ }^{64}$ Em outro ponto, Bourriaud descreve o projeto da arte como sendo o de "constituir um espaço dentro do qual o indivíduo possa finalmente manifestar a totalidade de sua experiência e inverter o processo desencadeado pela produção industrial, a qual reduz o trabalho humano à repetição de gestos imutáveis numa linha de montagem controlada por um cronômetro". Nicolas Bourriaud. Formas de Vida, p.13.

65 “embora eu possa apreciar a qualidade formal intrínseca de uma obra, o juízo estético se baseia igualmente na trajetória que a vincula à trajetória mental do autor, na textura desse universo estruturado que, através delas, esboça um projeto". Nicolas Bourriaud. Formas de Vida, p. 134-138.
} 
existência - da vida - do indivíduo que a experimenta. Como em Pollock que apresenta aqueles elementos característicos ao gênio, de modo que talvez já não possa ocorrer hoje. ${ }^{66}$

Algum tempo antes de Pollock, em 1922, Tristan Tzara, poeta e performer dadaísta, também assumia de certo modo aqueles traços característico do gênio, mas de modo bastante diverso, diluídos na vida. $\mathrm{O}$ artista dizia querer espontaneidade:

\begin{abstract}
não que ela seja mais bonita ou melhor do que as outras coisas. Mas porque tudo o que brota livremente de nós mesmos, sem a intervenção das ideias especulativas, nos representa. É preciso acelerar essa quantidade de vida que se gasta facilmente por toda parte. A arte não é a manifestação mais preciosa da vida. A arte não possui esse valor celestial e geral que gostam de lhe atribuir. A vida é muito mais interessante. ${ }^{67}$
\end{abstract}

Tzara recusava o "valor celestial" da arte, mas afirmando na vida a espontaneidade, "que brota livremente de nós mesmos", justamente um dos elementos mais característicos das noções mais místicas de genialidade. É claro que a contradição é traço característico do dadaísmo, mas não deixa de ser curioso notar como todos aqueles elementos referidos por Francis Bacon, p. ex., tão ajustados ao pensamento romântico, são eles mesmos expandidos ao máximo entre os dadaístas, a despeito da rejeição radical da "arte".

A meu ver, a possibilidade de realização daqueles ideais românticos da arte no contexto mais amplo da vida pode ser especialmente considerado em Marcel Duchamp, onde mesmo a exploração da descoberta filosófica do gênio inerente a toda sorte de atividade consciente pode ser considerada $^{68}$. O afastamento das convenções; o desregramento da vida; a suspensão de a prioris; a abertura ao acaso; a possibilidade de ter com o mundo um juízo reflexivo absolutamente indeterminado; a desinstrumentalização - inclusive do pensamento; e mesmo a união entre espírito científico e sentido artístico que define a ironia no romantismo ${ }^{69}$ estão presentes em Duchamp. Com

\footnotetext{
66 Se recusarmos a ideia tão criticada por pensadores como Hal Foster de uma qualidade "intemporal" ou "anistórica" inerente à pintura, e concordarmos com Harold Rosemberg que considerava a propósito de Pollock, "o último 'momento' da arte no plano da seriedade dramática e intelectual", "por ter ousado ser subjetiva e afirmar o artista como um Eu ativo" ROSEMBERG, H. "Action painting: Crise e distorções". In: FERREIRA G.; COTRIM, C. (Org.). Clement Greenberg e o Debate Crítico.

${ }^{67}$ Citado em Formas de Vida, de Nicolas Bourriaud, p. 72

${ }^{68}$ Ver nota sobre Duchamp, neste volume, p. 67.

${ }^{69}$ Márcio Suzuki. O Gênio Romântico, p. 188.
} 
efeito, Bourriaud demonstra uma possível afinação com o projeto político do romantismo quando escreve que Marcel Duchamp usou a arte "para estabelecer certo modo de vida, e tentar fazer de sua 'maneira de respirar, de reagir', uma espécie de 'quadro vivo'". Marcel Duchamp, que acreditava no emprego de seu tempo como a obra com a qual estava mais satisfeito, dizia acreditar

que a arte é a única atividade pela qual o homem enquanto tal se manifesta como autêntico indivíduo. Somente através dela ele consegue ultrapassar o estágio animal, porque a arte é uma saída para regiões não dominadas pelo tempo ou pelo espaço.

Indicando a natureza transformadora e possivelmente até transcendental da arte, o artista relaciona a possibilidade de movimentação em direção a regiões novas, desconhecidas, "não dominadas", à ideia, também fortemente romântica, de manifestação da autenticidade de um indivíduo. ${ }^{70}$ Porém, a exclusividade da relação proposta por Duchamp, e também sugerida por Marx, entre a atividade artística e a manifestação da autenticidade de um indivíduo hoje já não é bem certa. Com isso, quero considerar que a individualização e a manifestação de autenticidade passaram a ser estimuladas pelo mundo moderno, deixando de ser traços distintivos da arte. A sociologia contemporânea toma ambos os fenômenos de modo bastante central e os relaciona àquela fragmentação do mundo moderno que os artistas foram os primeiros a exprimir ${ }^{71}$. Como resultado, ao menos no plano da aparência (uma vez que se considera o caráter institucional dos processos habituais de individualização), deixa de haver uma massa homogênea a partir da qual o artista possa se distinguir com seu trabalho de modo tão evidente, e as pessoas tornam-se céticas com relação ao modo como os artistas podem constituir individualidades verdadeiramente distintas. Ao passo em que o homem e a mulher comum tornam-se, necessariamente, pelas próprias exigências do mundo moderno, mais autocentrados, concentrados, com seus fazeres e experiências, na produção de si mesmos, encontram-se na posição artistas. Naturalmente, a vida dos artistas reconhecidos e autoproclamados passa a interessar menos, pois sente-se que a experiência da liberdade é relativamente a mesma em todo caso. Em parte, isso define o sentimento de

\footnotetext{
70 "O supremo autoconhecimento é o da individualidade, do próprio Gênio". "A individualidade é justamente o que há de original e eterno no homem; a personalidade não importa tanto. Impulsionar, como vocação suprema, a formação e desenvolvimento da individualidade seria um egoísmo divino". Márcio Suzuki. O Gênio Romântico, p.112. Márcio Suzuki. O Gênio Romântico, p. 188.

${ }^{71}$ Ver nota sobre individualização (e a tendência à indistinção da arte), neste volume, p. 60.
} 
inexpressividade da arte em nossa época e sua indistinção aparente em relação às demais produções culturais - para muitos, sinal do fracasso do projeto vanguardista de fusão entre arte e vida.

Com isso, o artista tem a possibilidade de reconhecer que a distinção é algo, em certa medida ao menos, acessível a todos, o que nos permite compreender em certo sentido, o que já propunha de Duve, que todos são artistas. A partir daí, grande parte dos artistas contemporâneos deixa de esperar ou desejar o reconhecimento de sua distintividade, supostamente mais profunda e verdadeira, recusando-se a preencher de modo satisfatório um espaço que, por sua própria estrutura e tradição, pretende afirmar a distinção da arte e do artista. Para além do recurso comum à ironia, me interessa sobretudo compreender nessa chave a opção de certos artistas por trabalhar sobre os limites mais gerais de nossa experiência comum. Como pode-se considerar a partir de Lygia Clark:

\footnotetext{
Se a perda da individualidade é de qualquer modo imposta ao homem moderno, o artista oferece uma vingança e a ocasião de se encontrar. Ao mesmo tempo em que ele se dissolve no mundo, em que ele se funde no coletivo, o artista perde sua singularidade, seu poder expressivo. Ele se contenta em propor aos outros de serem eles mesmos e de atingirem o singular estado de arte sem arte $^{72}$
}

O "singular estado de arte" a que se refere Lygia Clark, está certamente relacionado àquele conhecido estado estético que interessava aos românticos. Assim, embora às margens do campo tradicional da arte, é interessante notar como para muitos artistas contemporâneos alguns dos elementos daquela tradição permanecem inalterados. A este respeito, quando Rancière recuperava Marx dizendo que é pelo trabalho "que a arte pode adquirir o caráter de atividade exclusiva", o filósofo chamava atenção para os pontos precisos em que a arte ainda difere em relação às demais atividades do espírito: justamente aquelas especificidades de seu trabalho que tornam a experiência estética uma possibilidade efetiva. A insistência de Ranciére em não considerar a arte uma "exceção" em relação à outras práticas tem o sentido de defender a possibilidade de "aplicação" daquele método de trabalho "integral" e "sem interesses" a campos mais amplos. A ênfase de Duchamp e dos dadaístas na vida, como ocorre em Lygia Clark, Helio Oiticica e diversos outros artistas, no limite, revela o desejo de estender a duração daquele momento de experiência "singular" para campos mais vastos. Helio Oiticica, com efeito, dizia sentir "que a vida em si mesma é o seguimento de toda experiência estética". ${ }^{73} \mathrm{~A}$ despeito da relativa indistinção da arte e do artista em relação ao que

\footnotetext{
${ }^{72}$ Lygia Clark. Citado em "A Arte Cura?”, de Suely Rolnik.

${ }^{73}$ Catálogo. Helio Oiticica. P. 135.
} 
habitualmente se considera não-arte e não artista em nossos dias, sabemos que estamos ainda muito longe disso. Nesse sentido, o que, a meu ver, Rancière destaca, é a importância de manter em andamento este projeto que no campo do trabalho, por exemplo, exige transformações radicais, pois indicaria a necessidade de reapropriação do tempo e dos meios de produção do trabalhador. 0 "modelo", em todo caso, permanece sendo aquela experiência descrita por artistas como Klee, e sugerida por Bacon.

Assim, considerando a recusa de alguns artistas em afirmar o caráter distintivo daquela experiência imediata em suas próprias produções, e admitindo estratégias que pretendam sua efetivação, é possível reconsiderar aquele esquema anteriormente proposto, admitindo a possibilidade de conciliamento entre artistas mais focados em uma experiência imediata e espontânea, e aqueles outros que propõe trabalhos mais conscientes e programados, muitas vezes irônicos. Se a estética lhes é central, ainda que se posicionem à margem dela e ainda que de modo indireto, é possível considerar estes trabalhos em relação às obras de artistas como Cèzanne, Klee, e Bacon, então compreendidas como registros dos encontros com estas experiências significativas e profundas que nos servem de modelo. Esta busca talvez possa ser considerada a partir de Kandinsky numa carta de 1938 que revela algo de seu estado de espírito durante o desenvolvimento de seu trabalho:

\footnotetext{
Nunca deixo de me alegrar por não ser político, e sim pintor. Assim eu fecho a porta do meu ateliê e o 'mundo' (o que eles hoje chamam de mundo) desaparece. Muito mais importante do que a Checoslováquia é para mim a questão de saber se este azul está bem colocado com aquele marrom, se esta extensão e a direção da linha combinam totalmente, se os 'pesos' foram colocados de maneira feliz etc. ${ }^{74}$
}

Se, como propomos, a prática artística pode ser compreendida como uma prática espiritual, e portanto, como um cuidado de si, é válido lembrar, com Foucault, antes de cobrar destes casos mais centrais de arte algum tipo de engajamento político ou "questão social" aparente, que "cuidar de si é também cuidar do outro", ou que a própria ideia de indivíduo implica uma dimensão social sem a qual ela não pode ser admitida - o indivíduo se estabelece a partir de relações, afinal. Daí que se expresse na relação que temos com as obras o papel social e político mais importante da arte, pois é a partir daí que temos a chance de experimentar, pelo trabalho dos outros, algo daquelas profundas experiências.

Não devemos, no entanto, perder de vista o fato de que as condições de efetivação destas experiências não são favoráveis, e, de todo modo, mesmo quando efetivas, elas "não duram", razão

\footnotetext{
${ }^{74}$ Citado em Vera D’Horta. Discordâncias Cordiais: a correspondência entre Kandinsky e Segall.
} 
pela qual, "voltando à vida", é necessário trabalhar para reduzir estas distâncias, sem esquecer, claramente, do sentido potencial do próprio trabalho. Pois se mantemos a meta de realização da vida como arte, então todas os esforços precisam culminar neste momento ideal de totalização e integração da experiência estética. Na pintura, pela superação da conhecida oposição entre figura e fundo, penso que os monocromos são possivelmente os símbolos máximos deste processo. É também em referência a ele que entendo o que Schlegel, certamente um dos pensadores românticos mais destacados, queria dizer quando considerava que os gregos antigos foram o que "o conjunto da humanidade deve voltar a ser - ‘uma pessoa, um indivíduo'”75. Para além dos gregos antigos, a ideia de reintegração do espírito, ou retorno ao Um, também aparece na sabedoria oriental, particularmente no zen e no hinduísmo. Também a ciência tem apontado para uma direção semelhante, no que me parece notável a proximidade de físicos como David Bohm e pensadores como Krishnamurti. Finalmente, muito mais próximos de nós, a cultura indígena preserva vivo, embora não sem dificuldades, este sentimento de unidade profunda - algo que se mostra particularmente vivo em rituais xamânicos. Ao assumir o caráter totalizante e espiritual da arte, estes laços possíveis tornam-se exploráveis. Como já sugeriam os românticos, a proximidade da arte com a religião - no sentido etimológico da palavra, justamente um movimento de religamento -, não deveria ser temida, pois ela permitiria o reestabelecimento de um sentimento profundo de que carecemos em uma época de interesses tão particulares.

É certo que, nessa perspectiva, uma narrativa específica da arte se encerra, mas uma narrativa que a compreendia a partir da própria fragmentação que permitiu, por exemplo, a consideração da produção "visual” num campo específico das artes. O movimento agora é outro. Insistir com isso no tema do "fim da arte" é propor a equivalência entre a arte a aquela narrativa particular, quando, na realidade, a história da arte se confunde com a história da humanidade se, reconhecendo o valor do processo, a compreendemos não apenas como o momento da experiência estética, mas como o fazer que tende a ela. O projeto de fusão entre arte e vida, com isso, permanece, não como utopia, mas como heterotopia. ${ }^{76}$ Nesse sentido, para reestabelecer laços rompidos de modo efetivo, penso que a arte faria bem se reconhecesse a afinidade inegável entre alguns de seus projetos mais significativos, e os da filosofia, de modo então a dar-lhe as boas-vindas de modo muito mais ativo.

Se a filosofia passar a ocupar o lugar da arte, não como coisa teórica ou abstrata, mas como modo de vida, ela passa a ocupar um outro lugar também no imaginário social e político, campos a partir dos quais, com o tempo, desencadeia certamente uma profunda transformação no que

\footnotetext{
${ }^{75}$ Em outra parte, Schlegel considera que “'a humanidade já é efetivamente uma única pessoa'”. Márcio Suzuki. O Gênio Romântico, p. 233-234.

76 Michel Foucault define heterotopias como "espécies de utopias realizadas". Ver em http://aufklarungsofia.files.wordpress.com/2011/06/outros_espacos.pdf.
} 
concebemos como realidade. Meu sentimento é que com tudo o que foi feito no campo artístico nos últimos séculos, particularmente sob a influência de figuras como Schiller e Duchamp, é somente agora, nesse momento histórico, que temos a possibilidade de assumir a chamada Revolução Estética e o projeto de fusão definitiva entre arte e vida, de modo a dar a estas questões a visibilidade que elas exigem. Meu sentimento é que curadores e artistas do mundo inteiro aos poucos vem tornando esta possibilidade consciente. É necessária assumi-la de modo definitivo. 


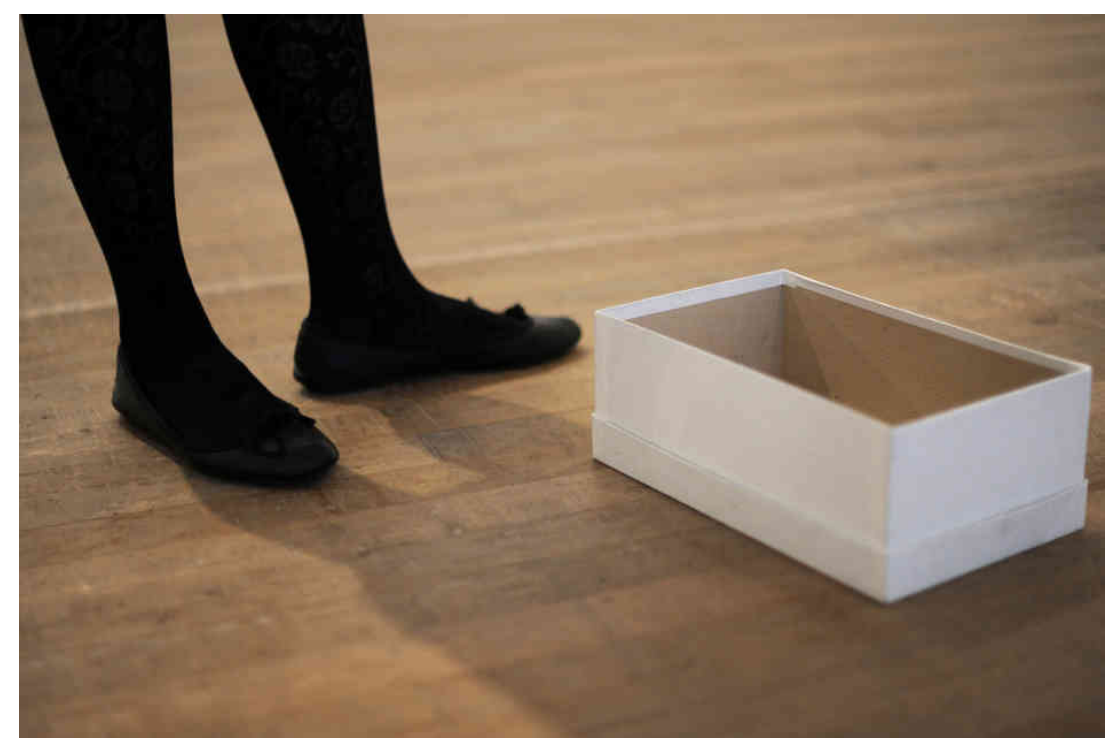

Empty Shoe Box. Gabriel Orozco, 1993. 
Notas 


\section{*Nota sobre individualização (e a tendência à indistinção da arte)}

Já Marx considerava no século XIX o modo como os indivíduos encontram suas condições de vida pré-estabelecidas por questões de classe. O problema seria precisamente a submissão do indivíduo a condições de vida e de trabalho pré-fixadas, e o fato daí decorrente de o indivíduo não ser o fazedor de sua própria vida. Mais recentemente, no entanto, parte da sociologia tem considerado o modo como estas condições pré-fixadas deixaram de ser certas com a modernidade, quando "tudo parece depender de decisão individual, já que as antigas referências à tradição, classe, família, cultura, local etc, tiveram sua legitimidade questionada e seu poder normativo esvaziado." A vida, com isso, perde sua "qualidade auto-evidente", e o homem torna-se "uma escolha entre possibilidades, homo optionis" ${ }^{77}$ : ideologia, aparência, gênero, identidade, religião, casamento, paternidade/maternidade, vínculos sociais etc, tudo passa a ser decidível. A liberdade, neste contexto, no entanto, é "precária", como definem Elisabeth e Ulrich Beck. Pois o que há em todas as áreas da existência é um número muito grande de opções a escolher, e a necessidade de escolhas rápidas. A suposta autenticidade do indivíduo se desenvolve aí a partir de um "exercício de liberdade" que se limita a realização de escolhas a partir de um leque dado de opções, o que grosso modo define a noção proposta pelos sociólogos de "indivíduos institucionalizados".

Como consequência, Ulrich Beck compreende a transmutação moderna do sujeito reflexivo de Descartes e Kant para o sujeito do "reflexo" ${ }^{78}$, mais adaptado à necessidade de escolhas rápidas e sucessivas em uma "sociedade de risco" que não oferece oportunidade de distanciamento. De modo muito semelhante o psicanalista Benilton Bezerra Jr., considerando os efeitos da modernidade sobre a constituição subjetiva dos indivíduos considera o que define como a "diluição da interioridade" e o desenvolvimento de "subjetividades epidérmicas" ${ }^{79}$ :

Não se trata, é claro, de afirmar de maneira mecanicista que mudanças objetivas

no mundo, como a implantação do projeto neoliberal na economia ou o

\footnotetext{
77 "Enquanto a modernidade ganha terreno, Deus, a natureza e o sistema social vão sendo progressivamente substituídos [...] pelo indivíduo". Ulrich Beck e Elisabeth Beck-Gernsheim. Individualization, p.5 -8.

${ }^{78} \mathrm{~A}$ diferenciação dos termos utilizados originalmente pelos autores, "reflective" e "reflexive", se perde na tradução, mas é bastante claro, se me permitirem preservar o inglês, como procura resumir Scott Lash no Prefácio de Individualization: "Beck often describes today's non-linear individual in terms of, not the 'I think therefore I am', but instead in terms of 'I am I'. 'I think, therefore I am' has to do with reflection. 'I am I' has more to do with reflex. And Beck often indeed works from the contrast of 'reflex' with reflection. Reflexive he argues has more to do with reflex than reflection. Reflexes are indeterminate. They are immediate. They do not in any sense subsume. Reflexes cope with a world of speed and quick decisionmaking". Ulrich Beck e Elisabeth BeckGernsheim. Individualization, p. ix.

79 Benilton Bezerra. "O ocaso da interioridade e suas repercussões sobre a clínica". In PLASTINO (org.). Transgressões. Rio: Contra Capa/Rios Ambiciosos
} 
surgimento de tecnologias de comunicação ou de intervenção biológica automaticamente causem mudanças nas formas de subjetivação, produzindo como consequência sujeitos diferentes. A maneira como a realidade político-econômica de uma sociedade afeta a subjetividade e o mundo psíquico dos indivíduos é mais complexa e indireta, e se dá fundamentalmente por meio da criação de certos ideais, da valorização de modelos de pensamento, da propagação de certos repertórios de conduta, da difusão de metáforas que se incorporam ao senso comum, enfim pela criação de novos jogos de linguagem, repertório de sentidos ou jogos de verdade que dão consistência ao imaginário de uma época, imaginário através do qual o mundo, a existência e a experiência pessoal ganham consistência e significação ${ }^{80}$.

Deslocadas as questões para o âmbito da arte, compreendemos que as bem conhecidas condições plurais da arte, ou mesmo a desorientação daí resultante, não são exclusividades do campo artístico. Além disso, reduzidas as condições de produção de trabalhos reflexivos, podemos compreender aí a crise da noção de experiência estética que já em Kant tratava-se justamente de uma atividade reflexiva. Como resultado, o distanciamento que a autonomia da arte deveria assegurar não garante na maior parte dos casos a distinção que se esperaria da arte. Antes, boa parte das instituições e trabalhos de arte se encaminham, junto às "tendências", em direções cada vez mais "epidérmicas". Como se aquela conhecida significação da arte, não tendo onde se escorar, passasse a afirmar-se pelas bordas. Daí o caráter espetacular de certas propostas e de certas produções muito bem estabelecidas que gravitam em torno da arte, como as Bienais; a arquitetura imponente de certos espaços expositivos; a organização curatorial que preserva certa ideia de pureza "impecável"; e mesmo a postura respeitosa por parte do público que muitas vezes nada fala ou toca, nem quando pode. Vale considerar sobretudo como as cotações a que chegam a atingir certas obras no mercado financeiro serve para de certa maneira objetivar e fazer sentir aqueles graves sentidos da arte, que como experiência estética propriamente dita tornaram-se algo como um mito. A sobreposição de valores torna-se delicada, e no mínimo atrapalha aquele "desinteresse" anteriormente idealizado. O que de fato parece sustentar a "aura" que ainda se faz sentir sobre a arte com alguma legitimidade é o reconhecimento do valor histórico de determinadas obras do passado, e o que pensaram dela algumas das cabeças mais inspiradas que se ocuparam de registrar

\footnotetext{
${ }^{80}$ Ao considerar, no final de sua reflexão, as possíveis implicações positivas deste processo de "diluição da interioridade", Bezerra considera que "talvez possamos nos livrar das 'tiranias da intimidade' (Sennet 1988) que se tornaram substância da subjetividade burguesa, com o privilégio da introspecção sobre a ação e ênfase excessiva no mundo privado em detrimento do público". (...) "Quem sabe se torne mais visível o fato de que somos constituídos por laços sociais e que autonomia implica dependências relativas." Benilton Bezerra. "O ocaso da interioridade...".
} 
seus pensamentos ao longo da história. Mas mesmo a história e a filosofia, nesse contexto, são utilizadas para acrescer o valor de fetiche da arte ${ }^{81}$.

\footnotetext{
${ }^{81} \mathrm{~A}$ respeito de todo o aparato que se desenvolve ao redor da arte, Pierre Bourdieu escreve que seja um "universo de crença que produz o valor da obra como fetiche": "A crença coletiva no jogo e no valor sagrado de suas apostas, é a um só tempo a condição e o produto do funcionamento mesmo do jogo; é ela que está no princípio do poder de consagração que permite aos artistas consagrados constituir certos produtos, pelo milagre da assinatura (ou da grife) em objetos sagrados." Pierre Bourdieu. As regras da arte: gênese e estrutura do campo literário.
} 


\section{* Nota sobre a autonomia da arte}

O curso dos acontecimentos deu ao gênio da época uma direção que ameaça afastá-lo mais e mais da arte do Ideal. Esta tem de abandonar a realidade e elevar-se, com decorosa ousadia, para além da privação; pois a arte é filha da liberdade e quer ser legislada pela necessidade do espírito, não pela privação da matéria. Hoje, porém, a privação impera e curva em seu jugo tirânico a humanidade decaída. A utilidade é o grande ídolo do tempo; quer ser servida por todas as forças e cultuada por todos os talentos. Nesta balança grosseira, o mérito espiritual da arte nada pesa, e ela, roubada de todo estímulo, desaparece do ruidoso mercado do século. Até o espírito de investigação filosófica arranca, uma a uma, as províncias da imaginação, e as fronteiras da arte vão-se estreitando à medida que a ciência amplia as suas.

Schiller, Carta II.

Schiller, autor das Cartas sobre a Educação estética do Homem, reconhecia o contexto desfavorável à arte durante à modernidade, mas, diferente de Hegel, acreditava na potencialidade "totalizante" da experiência artística para alterar o quadro geral daquele período. Enquanto o filósofo e poeta falava de uma possível "educação estética", Hegel afirmava numa referência clara ao projeto schilleriano, que "nem por meio de uma educação específica ou de um distanciamento das relações humanas [seria possível] fabricar e formar uma solidão particular, restauradora do que se perdeu" - nem "por vontade e decisão pessoais", as condições do mundo moderno poderiam ser abstraídas.

Estando ambos de acordo quanto as condições gerais da modernidade não serem favoráveis à arte, a partir das diferenças entre Schiller e Hegel inúmeras aproximações podem ser consideradas ao longo da história da arte. Numa linha talvez mais próxima à hegeliana, por exemplo, muitos artistas e pensadores desejaram, ao invés do distanciamento da arte, o envolvimento direto e efetivo com estas mesmas condições que lhe eram desfavoráveis. Se nestes casos a arte não abandona seus sentidos mais profundos de transformação (posto que, como dirá Foucault, a espiritualidade é questão que se coloca também em correntes de pensamento como o marxismo, justamente por seus objetivos profundos de mudança ${ }^{82}$ ), eles são ao menos prévia e estrategicamente postos de lado: a arte passa então a servir a um projeto político de transformação social mais amplo. Isto pode ser pensado desde o chamado "realismo socialista", relacionado pelo

${ }^{82}$ Michel Foucault. A Hermenêutica do Sujeito, p.28. 
crítico de arte Mário Pedrosa a uma "mentalidade totalitária" típica à época ${ }^{83}$, até o situacionismo de Guy Debord, por exemplo.

Do lado de Schiller, poderíamos considerar aqueles que afirmam a autonomia da arte, noção que se desenvolve desde pelo menos o Renascimento, quando o artista distingue-se dos artesãos, e se estabelece principalmente a partir dos escritos de Kant, no século XVIII. A autonomia da arte pode ser pensada como uma aposta contrária à perspectiva hegeliana. A afirmação da ideia de que a arte, como obra do espírito, seria "livre", pela própria autonomia do juízo estético, pretendia assegurar, afinal, o que seria seu traço distintivo em relação às demais atividades do espírito. Pois se de início a arte não poderia ser compreendida em oposição à ordem instituída, já que apenas "uma arte que tenha atingido uma relativa autonomia pode tomar posição" ${ }^{84}$, agora ela descobre, como dirá Marcuse, seu "potencial subversivo" e se torna uma "força dissidente." ${ }^{85}$ É a exploração deste potencial e desta força que dá origem às vanguardas no final do século XIX ${ }^{86}$, junto ao conhecido projeto de fusão entre arte e vida, marcadamente influenciado pelo pensamento romântico e schilleriano.

Para Herbert Marcuse, a "obra de arte verdadeira" seria "uma acusação da realidade estabelecida, [e] a aparição da imagem da libertação. ${ }^{\prime 87}$ Contrário à maior parte da crítica marxista que, segundo o filósofo, esperava, ou mesmo exigia do potencial "subversivo" e "libertador" da arte, certo comprometimento com relação a causas políticas e sociais, Marcuse considerava que "quanto mais imediatamente política for a obra de arte, mais ela reduz o poder de afastamento e os objetivos radicais e transcendentes de mudança". Peter Bürger, num mesmo sentido considerava que

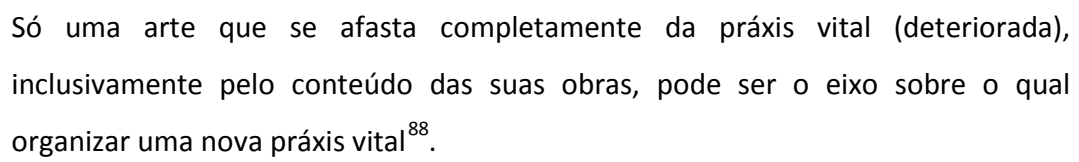

\footnotetext{
${ }^{83}$ Mário Pedrosa. Arte e Revolução, em Mundo, Homem, Arte em Crise, p. 247.

84 “A arte completamente ligada ao ritual não pode ter estado alinhada porque não pode dar-se como um âmbito especial. A obra de arte é aqui parte do ritual. Só uma arte que tenha atingido uma relativa autonomia pode tomar posição. Assim, pois, a autonomia da arte é também a condição de uma heteronomia posterior. A estética da mercadoria pressupõe uma arte autônoma" (Peter Bürger, 1993, nota 8, pg. 98).

${ }^{85}$ Herbert Marcuse. A dimensão estética.

${ }^{86}$ Mostras independentes como a de Courbet, realizada em 1855, e o conhecido Salão dos recusados, de 1863 , são considerados marcos do surgimento da vanguarda. A respeito do primeiro, Yve-Alain Bois escreve que "representa o primeiro gesto de vanguarda, um gesto de desafio contra o domínio sempre crescente da mercadoria".

${ }^{87}$ Herbert Marcuse. A Dimensão estética.

${ }^{88}$ Peter Burger. Teoria da Vanguarda. Pg. 91.
} 
A autonomia da arte, assim, é compreendida como possibilitadora de "uma ordem alheia ao princípio de máximo lucro dominante sobre a totalidade da vida". Mário Pedrosa, de modo muito semelhante, destacava a "superação das práticas humanas estabelecidas" pelas atividade desinteressadas do espírito, que deveriam ser "desenvolvidas independentemente dos condicionamentos sociais." ${ }^{89}$ A proximidade com Schiller talvez possa ser considerada quando Mário Pedrosa evoca a "alma" ao falar em "revolução da sensibilidade" ${ }^{90}$, e quando Marcuse dá ênfase na "subjetividade dos próprios indivíduos, na sua inteligência e nas suas paixões, nos seus impulsos e nos seus objetivos". ${ }^{91}$

É claro, porém, que a autonomia da arte a estas alturas já era compreendida de modo bastante desencantado. ${ }^{92}$ Para muitos pensadores, o "mercado" coloca em xeque tanto práticas tradicionais, como a pintura ${ }^{93}$, quanto movimentos que se pretenderam alternativas ao modelo tradicional, como a arte conceitual e a site-specific, ${ }^{94}$ então caídas em descrédito. ${ }^{95}$ Já Peter Bürger

\footnotetext{
89 "Contra o mecanicismo sócio-econômico, uma defesa possível consistia em manter o avanço das atividades livres não apenas para denunciar a subordinação do homem às determinações históricas do capitalismo e a incapacidade de controle e de direcionamento racional nos regimes políticos vigentes, mas também para insuflar vida no esquema de relações sociais quase inanimadas a fim de que se iniciasse o processo construtivo de uma nova sociedade". Marcelo Mari, Política das artes. Mário Pedrosa e a defesa da arte independente"
}

90 “...a revolução da sensibilidade, a revolução que irá alcançar o âmago do indivíduo, sua alma, não virá senão quando os homens tiverem novos olhos para olhar o mundo, novos sentidos para compreender suas tremendas transformações e intuição para superá-las. Está será a grande revolução, a mais profunda e permanente..." Mário Pedrosa. Arte e Revolução, em Mundo, Homem, Arte em Crise, p. 247.

91 "A subjetividade dos indivíduos, a sua própria consciência e inconsciência tendeu a ser dissolvida na consciência de classe. Assim, é minimizado um importante pré-requisito da revolução, nomeadamente o fato de que a necessidade de mudança radical se deve basear na subjetividade dos próprios indivíduos, na sua inteligência e nas suas paixões, nos seus impulsos e nos seus objetivos." Marcuse. A Dimensão Estética.

92 "A autonomia estética foi engendrada pela lógica do capitalismo da produção de commodity tanto quanto se opôs a esta lógica". Benjamin Buchloh, na segunda introdução ao livro Art from 1900, escrito conjuntamente com Rosalind Krauss, Hal Foster e Yve-Alain Bois.

93 "nunca foi mais evidente que a maioria das pinturas que se vê abandonou a tarefa que historicamente pertenceu à pintura moderna(...) sendo meros artefatos criados para o mercado e pelo mercado (artefatos absolutamente intercambiáveis, criados por produtores intercambiáveis)". Yve-Alain Bois. A Pintura como Modelo, p. 291.

94 “...tendo feito definhar os modos 'efêmeros' (...), [o mercado] , torna-se de novo voraz por arte 'intemporal'”. Hal Foster. Recodificação, p. 35.

95 Lucy Lippard considera já em 1977 "infundadas" as esperanças de evitar a comercialização ou "a tirania do status de commoditie e da orientação para o mercado." Ainda que a crítica americana reconheça a "considerável contribuição estética" desta produção, ela considera "improvável que a arte conceitual vá estar de alguma maneira melhor equipada para afetar o mundo de uma maneira diferente do que, ou mesmo tanto quanto, suas contra-partes menos efêmeras." Para ela, "arte e artistas em um sociedade capitalista não são mais do que luxo." Lucy Lippard, no posfácio de Six Years, the dematerializatin of the art object from 1966 to 1972. Num sentido 
em sua época considera o "fracasso" das vanguardas; Mário Pedrosa fala de um "otimismo (..) barrado", e considera um período de "decadência"; ${ }^{96}$ artistas como Lygia Clark no final dos anos 60 anunciam o temor de "domesticação"; ${ }^{97}$ Hal Foster no início da década de 80 nota a tendência à “impotência" e "irrelevância" da arte ${ }^{98}$; outros pensadores em períodos mais recentes sugerem o aspecto "agonizante" da arte como traço constitutivo da própria contemporaneidade, ${ }^{99}$ ou destacam a perda de sua dimensão transcendente e sua "conveniência" no contexto mais amplo da cultura. ${ }^{100}$

Uma vez que as condições desfavoráveis à arte eram conhecidas desde o princípio, as coisas permanecem entre Hegel, quando se recupera com isso o tema do fim da arte, ou Schiller, quando se preserva o projeto de emancipação pelo plano estético. Entre uma coisa e outra, sugerindo uma posição possivelmente intermediária, a crítica e curadora Clarissa Diniz, num estudo bastante recente, relaciona a redução da força de transformação da arte à "questão social" sob a perspectiva de certa "cultura do voluntariado". Clarissa Diniz problematiza a tendência à adesão consensual ao "projeto neoliberal e sinérgico" do "agir junto", e chega a questionar "o que diferenciaria as escolhas políticas da arte das estratégias sociais e políticas (...) das grandes corporações." 101

semelhante, Guy Brett considera que "a tentativa de desafiar a versão museológica da cultura é vã. Obras que propõem ou almejam a 'dissolução da arte na vida' acabam no contexto de um museu, no qual parecem relíquias mais tristes que outras que aceitaram a estrutura do museu e trabalharam dentro dela." Guy Brett. Brasil experimental: arte/vida: proposições e paradoxos. Org. Katia Maciel. Editora Contra Capa.

96 "a avalancha do mercado barrou nosso otimismo" Mário Pedrosa, citado em Itinerário Crítico, de Otília Arantes. Pg. 166

${ }^{97}$ Se eu fosse mais jovem, faria política. Sinto-me por demais à vontade. Integrada demais. Antes, os artistas eram marginalizados. Hoje, nós, propositores, estamos muito bem colocados no mundo. Conseguimos sobreviver apenas propondo. Há um lugar para nós na sociedade. (...) às vezes me pergunto se não estamos um pouco domesticados. Isso me chateia..." Lygia Clark. "Estamos Domesticados?". Disponível em http://www.lygiaclark.org.br/arquivo_detPT.asp?idarquivo=29

${ }^{98} \mathrm{Hal}$ Foster se refere particularmente às tendências da arte após o que considera sua "dispersão" após os anos 60. O foco principal de sua análise é a produção dos anos 80 tradicionalmente referida como a d"o retorno da pintura". Em "Contra o pluralismo". Hal Foster. Recodificação, p. 33-55.

99 Ver por exemplo "Arte Contemporânea e banalização do mal: o silêncio do espectador", de João A. FrayzePereira, em Arte, Dor. Inquietudes entre estética e psicanálise. Cotia, SP: Ateliê Editorial, 2005.

${ }^{100}$ George Yúdice. A conveniência da cultura: usos da cultura na era global. Belo Horizonte: Editora UFMG, 2006.

${ }^{101}$ Clarissa Diniz. Partilha da Crise: ideologia e idealismos. 


\section{*Nota sobre Duchamp}

Onde quer que o encontremos, este tratamento espirituoso e esteticamente livre da realidade comum é o sinal de uma alma nobre. Deve ser dita nobre a alma que tenha o dom de tornar infinitos pelo modo de tratamento, mesmo o objeto mais mesquinho e a mais limitada empresa. É nobre toda forma que imprime o selo da autonomia àquilo que, por natureza, apenas serve (é mero meio). Um espírito nobre não se basta com ser livre; precisa pôr em liberdade todo o mais à sua volta, mesmo o

inerte.

Schiller, Carta XXIII

As peças [de xadrez] não são belas por elas mesmas, assim como a forma do fogo, mas o que é belose a palavra "'belo' pode ser usada - é o movimento. (...) No xadrez, existem, sem dúvida, coisas extremamente belas no domínio do movimento, mas não do domínio do visual. Imaginar o movimento ou o gesto é que faz a beleza neste caso. Está completamente dentro da massa cinzenta.

Marcel Duchamp

\section{Vestígios do pensamento romântico em Duchamp e o nascimento do artista curador}

O projeto de retomada das dimensões espirituais da arte na contemporaneidade precisa compreender Marcel Duchamp, certamente um dos artistas, se não o artista, mais influente(s) da modernidade. Para isso, creio ser possível partir da reapropriação e embaralhamento das noções tradicionalmente opostas de artista, então compreendido como "gênio que cria obras de arte", e receptor-fruidor, o "indivíduo de gosto que contempla o belo". Quando Duchamp afirmava a respeito de seus ready-mades que dispensava "o deleite estético", era a categoria tradicional do belo o que repudiava, não evidentemente o jogo estético, a atitude perceptiva e reflexiva frente à obra, como um todo. Ao revelar o desejo de encontrar objetos esteticamente "indiferentes" - objetos em relação aos quais não se costuma estabelecer qualquer juízo reflexivo -, Duchamp dispensa o gosto ao mesmo tempo em que apanha a noção de "desinteresse", então central à experiência estética, sugerindo que naquilo que se chamou belo, o que há de mais relevante é a indeterminação da experiência: o fato de que nenhum conceito seria propriamente adequado para apreender o dado 
sensível e dar fim as suas possibilidades de sentido. Esta impossibilidade de apreensão definitiva da Ideia estética é o que mantém o juízo reflexivo em atividade, e a arte livre, algo que já Schlegel propunha que poderia ocorrer com todos os objetos ${ }^{102}$. Com efeito, o deslocamento de Duchamp sugere o reconhecimento de gênio em toda obra humana, que a natureza de nossa experiência depende de contextos, e a desinstrumentalização do mundo, de uma mudança de atitude em relação à sua dimensão estética.

Duchamp é o primeiro a fazer uso irônico da instituição para fazer uma crítica a ela mesma e a toda a tradição em que se baseia. Seu domínio técnico se resume, nos ready-mades, à operação de apropriações e deslocamentos, promovendo espécies de composições que se tornam significativas pelos contextos gerais, processo que o aproxima muito mais do trabalho do curador, tal como o conhecemos hoje, do que do artista segundo a tradição. De fato, embora o artista fale em "coeficiente artístico" e a despeito de todo o non-sense dadaísta, é difícil conceber de que modo noções tradicionalmente importantes ao artista, como instintividade ou irracionalismo, se adequariam a estes casos. Antes, a operação de Duchamp parece revelar o interesse de não apenas aproximar arte da (habitualmente considerada) não-arte, mas também o artista do não-artista. 0 nome "fonte" de seu ready-made mais conhecido, p. ex., coloca em evidência, pela própria ambiguidade, este lugar entre o objeto e o espectador, remetendo à ideia de um público-criador (embora pela própria natureza do objeto em questão, apele especificamente ao público masculino $)^{103}$. Aí sim, talvez, a imprevisibilidade ou mesmo o instinto possam ser considerados: na reação de estranhamento do público com sua súbita promoção à categoria de artista. De todo modo, com ênfase em nosso modo de relação com os objetos, Duchamp propõe que a libertação das coisas do mundo dependeria mais da atitude do homem em relação aos vínculos necessários que possui com a natureza - basicamente o que the obriga a produzir coisas -, do que de um suposto rompimento com estes vínculos por meio de nossa inteligência técnica, como se fosse possível livrar-

102 Friedrich Schlegel, filósofo romântico, questiona a estética tradicional e a restrição da categoria do Belo à objetos específicos já no século XIX. Compreendendo que a rejeição de Duchamp tem em vista a concepção tradicionalmente restritiva do belo, creio ser possível e proveitoso reconciliá-lo à noção através do filósofo: "Se toda a natureza é obra de um grande poeta, então só uma compreensão filosófica parcial do universo pode pretender instituir uma estética, disciplina que se incumbe de destacar e recortar certas manifestações do conjunto da criação, como se fosse possível distinguir as qualidades estéticas e o significado dos objetos: 'A essência da beleza', adverte Schlegel, 'concorda rigorosamente com a significação. É bastante incorreto querer limitar o belo somente a algumas coisas, e não o estender a todas'. Tudo pode ter o predicado da beleza, e a própria invenção da estética é apenas a resposta igualmente equivocada a uma ciência que não sabe ver e reconhecer a 'significação espiritual dos objetos' Márcio Suzuki. O Gênio Romântico. p.149-150.

${ }^{103}$ Como escreve o artista em 1965, "o público estabelece o contato entre a obra de arte e o mundo exterior, decifrando e interpretando suas qualidades intrínsecas e, desta forma, acrescenta sua contribuição ao ato criador". O ato criador. Marcel Duchamp. Em outra parte o artista chega a considerar que "os espectadores é que criam os quadros". Citado em Formas de vida. Nicolas Bourriaud, p. 185. E ainda no livro de entrevistas à Pierre Cabanne: "Dou tanta importância àquele que a vê [a obra] quanto àquele que a faz". Marcel Duchamp: Engenheiro do tempo Perdido. P. 122. 
se em definitivo da necessidade, e nunca mais retornar a ela. Ora, este processo de libertação em relação à natureza tem o sentido de acentuar as cisões modernas como as que compreendem a liberdade em oposição à natureza, o pensamento em oposição ao corpo, e assim por diante. Duchamp, ao contrário, sugere um modo estético de relação com o necessário, e assim, com o próprio corpo e a natureza. 


\section{* Nota sobre a espiritualidade.}

Uma das questões centrais do livro A hermenêutica do Sujeito ${ }^{104}$, de Michel Foucault, onde o filósofo examina a relação entre sujeito e verdade, é a noção de espiritualidade. A espiritualidade é compreendida no âmbito das condições pelas quais o sujeito pode ter acesso à verdade, e é definida por Foucault segundo uma fórmula: “A verdade só é dada ao sujeito a um preço que põe em jogo o ser mesmo do sujeito. Pois, tal como ele é, não é capaz de verdade."

Definindo a verdade como "o que ilumina o sujeito; (...) o que lhe dá beatitude; (...) o que Ihe dá tranquilidade de alma" - "na verdade e no acesso à verdade, há alguma coisa que completa o próprio sujeito, que completa o ser mesmo do sujeito e que o transfigura" -, o filósofo explica que, segundo o pensamento grego, para ter acesso à verdade é necessário que o sujeito "se modifique, se transforme, se desloque, torne-se, em certa medida e até certo ponto, outro que não ele mesmo." Sem essa transformação, "o sujeito enquanto tal não (...) possui capacidade de ter acesso à verdade", nem mesmo por um ato de "simples conhecimento", pois ele seria fundamentado e legitimado pelo sujeito em sua estrutura habitual de sujeito. "Isso acarreta, como consequência, que desse ponto de vista não pode haver verdade sem uma conversão ou sem uma transformação do sujeito". Segundo Foucault, esta transformação pode ocorrer de duas grandes formas, por força de éros (amor), ou pela ascese (áskesis). No primeiro caso, trata-se de "um movimento que arranca o sujeito de seu status e de sua condição atual", movimento de ascensão do próprio sujeito, pelo qual a verdade vem até ele e o ilumina; no segundo caso, o acesso à verdade se daria ao longo de um trabalho de si para consigo, em que o próprio sujeito seria responsável pela transformação de si para consigo mediante um longo labor. É nesse âmbito que a noção de cuidado de si é examinada desde a Grécia antiga pelo autor, até a modernidade, quando Foucault identifica uma ruptura: a modernidade propõe a suficiência do conhecimento para ter acesso à verdade, sem que o sujeito em seu ser mesmo de sujeito tenha que passar por qualquer processo de transformação, o que indica um desprendimento em relação às condições mesmas da espiritualidade. $\mathrm{O}$ acesso à verdade na modernidade "nada mais encontra[..] no conhecimento, como recompensa e completude, do que o caminho indefinido do conhecimento", e aquele ponto de iluminação transfigurante estaria então relegado ao passado. Contudo, Foucault afirma que "todo o interesse da situação está precisamente, em que os vínculos [espiritualidade - verdade] não foram bruscamente rompidos como que por um golpe de espada".

Foucault considera o conflito entre espiritualidade e pensamento teológico muito mais determinante para esta ruptura do que o desenvolvimento do pensamento científico. Podemos

\footnotetext{
${ }^{104}$ A Hermenêutica do Sujeito reúne o conteúdo de um curso ministrado por Michel Foucault no início de 1982. Todas as citações presentes ao longo deste texto foram retiradas do livro.
} 
imaginar que o apontamento pelo pensamento teológico de um lugar de iluminação e completude de "verdade" - no além do sujeito, "fora" dele (o que estaria relacionado a noções como a de renúncia de si), teria feito minguar a espiritualidade no Ocidente. Se isto é correto, então é certamente possível relacionar a retirada da dimensão espiritual do âmbito mais amplo da vida do sujeito ao "abandono do mundo a um conflito de interesses" ${ }^{105}$, como considera Horkheimer em $O$ eclipse da Razão. O desenvolvimento do racionalismo técnico e instrumental seria assim subsequente ao fenômeno moderno da perda da possibilidade de verdade no mundo propriamente presente, de modo então que o desenvolvimento do pensamento científico, o desenvolvimento do pensamento teológico e o ocaso da espiritualidade estariam todos intimamente relacionados. Naturalmente, em contexto tão desfavorável à espiritualidade, podemos considerar o esforço histórico de resguardar ao menos parte do "conjunto de buscas, práticas, experiências" que a definiriam. É neste contexto que a autonomia estética é reivindicada, como para resguardar o potencial espiritual e transformador das práticas que naquele período foram reunidas sob o rótulo "belas-artes".

${ }^{105}$ Max Horkheimer, O Eclipse da Razão, 1947. 
Arte,

vida,

filosofia

os termos se confundem,

o resultado é poesia! 


\section{Referências}

BASBAUM, Ricardo. Além da Pureza Visual. Porto Alegre: Zouk, 2007.

BECK, Ulrich; BECK-GERNSHEIM, Elisabeth. Individualization. Institutionalized Individualism and its Political and Social Consequences. London: Sage Publications, 2002.

BEZERRA, Benilton. "O ocaso da interioridade e suas repercussões sobre a clínica". In PLASTINO (org.). Transgressões. Rio: Contra Capa/Rios Ambiciosos, 2002.

BOIS, Yve-Alain. A Pintura como Modelo. São Paulo: Martins Fontes, 2009.

BOURRIAUD, Nicolas. Formas de Vida. A Arte Moderna e a invenção de si. Martins Fontes, 2011.

BOURDIEU, Pierre. As Regras da Arte. São Paulo: Companhia das Letras, 1996.

BRAGA, Paul (Org.). Seguindo Fios Soltos: caminhos na pesquisa sobre Hélio Oiticica. Edição especial da revista Fórum Permanente (www.forumpermanente.org). Acessado pela última vez em 09/2013.

BÜRGER, Peter. Teoria da Vanguarda. Tradução: Ernesto Sampaio, 1993.

CABANNE, Pierre. Marcel Duchamp: Engenheiro do tempo perdido. Tradução de Paulo José Amaral. São Paulo: Perspectiva, 2008.

DANTO, Arthur. Após o Fim da Arte. A Arte Contemporânea e os Limites da História. Trad. Saulo Krieger. Sâo Paulo: Odysseus Editora, 2006.

DE DUVE, Thierry. "Kant depois de Duchamp". Revista do Mestrado em História da Arte EBA - UFRJ, 1998.

DE DUVE, Thierry. Revista Concinnitas, vol. 7, 2004

D'HORTA, Vera. Discordâncias Cordiais: a correspondência entre Kandinsky e Segall. Disponível em: http://www.unicamp.br/chaa/rhaa/downloads/Revista\%201\%20-\%20artigo\%2015.pdf. Acessado pela última vez em 09/2013.

DINIZ, Clarissa. Partilha da Crise: ideologia e idealismos. Disponível em: http://www.lastroarte.com/files/textos/clarissa-diniz/partilha-da-crise-clarissa-diniz.pdf. Acessado pela última vez em 09/2013.

DUCHAMP, Marcel. "O ato criador"; "Sobre os readymades"; "O caso R. Mutt". Disponíveis em: http://asno.files.wordpress.com/2009/06/duchamp.pdf. Acessado pela última vez em 09/2013.

FOSTER, Hal. Recodificação: arte, espetáculo, política cultural. Tradução de Duda Machado. Casa Editorial Paulista. 1996.

FOSTER, Hal. [Et al.] Art Since 1900: modernism, antimodernism, postmodernism. London. Thames \& Hudson, 2004.

FOUCAULT, Michel. A Hermenêutica do Sujeito. São Paulo, Martins Fontes. 2006. 
FREIRE, Cristina. Isidoro Valcárcel Medina no MAC USP. São Paulo, Edusp, 2013.

GOETHE, J. W. v., SCHILLER, F. Goethe e Schiller. Companheiros de viagem. Nova Alexandria, São Paulo, 1993.

HADDOCK-LOBO, Rafael (Org.). Os Filósofos e a Arte. Rio de Janeiro: Rocco, 2010.

GRAMSCI. "Espontaneidade e direção consciente". Escritos Políticos. 1931. Disponível em: http://gramsci-brasil.blogspot.com.br/2007/10/espontaneidade-e-direo-consciente.html. Acessado pela última vez em 09/2013.

GREENBERG, Clement. Clement Greenberg e o Debate Crítico. Organização, apresentação e notas: Glória Ferreira e Cecília Cotrim de Mello; tradução: Maria Luiza X. de A. Borges. Rio de Janeiro: Jorge Zahar Ed. 2001.

HEGEL, G.W.F. Cursos de Estética. Vol 1. Trad. Marco Aurélio Werle; São Paulo: Edusp, 2001.

HORKHEIMER, Max. (1976 [1947]) Eclipse da razão. Rio de Janeiro: Editorial Labor do Brasil. 1973

KANT, Immanuel, Crítica da faculdade do juízo. Trad. Valério Rohden e Antonio Marques. Rios de Janeiro: Forense Universitária, 1993.

MARCUSE, Herbert. A Dimensão estética. São Paulo: Martins Fontes, 1986.

MARX, Karl. Manuscritos econômico-filosóficos e outros textos escolhidos. Coleção Os Pensadores. Rio de Janeiro: Abril Cultural, 1974. [Seleção de José Arthur Giannotti]

MERLEAU-PONTY, Maurice. O Olho e o espírito. Trad. Paulo Neves e Maria Ermantina Galvão. Cosac \& Naify, 2004.

PEDROSA, Mário. Mundo, Homem, arte em Crise. São Paulo: Editora perspectiva, 1975.

RANCIÈRE, Jacques. A partilha do Sensível: Estética e Política. Tradução de Mônica Costa Netto. São Paulo: EXO experimental org.; Ed. 34, 2005.

RICHTER, Hans. Dadá: arte e antiarte. Tradução de Marion Fleischer. São Paulo: Martins Fontes, 1993.

SCHILLER, Friedrich. A Educação Estética do Homem numa séria de cartas. Tradução de Roberto Schwarz e Márcio Suzuki. Introdução e notas, Márcio Suzuki. Editora Iluminuras, 1989.

SYLVESTER, David. Entrevistas com Francis Bacon. Tradução de Maria Teresa Resende Costa. São Paulo: Cosac Naify, 2007.

SUZUKI, Márcio. O Gênio Romântico: Crítica e História da Filosofia em Friedrich Schlegel. São Paulo: Ed. Iluminuras, 1998.

WERLE, Marco Aurélio e GALÉ, Pedro Fernandes (Orgs.) Arte e filosofia no Idealismo Alemão. São Paulo: Editora Barcarolla, 2009. 